\title{
G-Protein-Coupled Inwardly
} Rectifying Potassium (GIRK) Channel Activation by the p75 Neurotrophin Receptor Is Required for Amyloid $\beta$ Toxicity

\begin{abstract}
Linda M. May ${ }^{1}$, Victor Anggono ${ }^{1,2}$, Helen M. Gooch ${ }^{1}$, Se E. Jang ${ }^{1,2}$, Dusan Matusica ${ }^{1,3}$, Georg M. Kerbler ${ }^{1}$, Frederic A. Meunier ${ }^{1,2}$, Pankaj Sah ${ }^{1}$ and Elizabeth J. Coulson 1,2,4*

${ }^{1}$ Queensland Brain Institute, University of Queensland, Brisbane, QLD, Australia, ${ }^{2}$ Clem Jones Centre for Ageing Dementia Research, University of Queensland, Brisbane, QLD, Australia, ${ }^{3}$ Centre for Neuroscience, College of Medicine and Public Health, Flinders University, Adelaide, SA, Australia, ${ }^{4}$ School of Biomedical Sciences, University of Queensland, Brisbane, QLD, Australia
\end{abstract}

Alzheimer's disease is characterized by cognitive decline, neuronal degeneration, and the accumulation of amyloid-beta $(A \beta)$. Although, the neurotoxic $A \beta$ peptide is widely believed to trigger neuronal dysfunction and degeneration in Alzheimer's disease, the mechanism

OPEN ACCESS

Edited by:

Marco Antonio Maximo Prado, University of Western Ontario, Canada

Reviewed by:

Sergio T. Ferreira, Federal University of Rio de Janeiro,

Brazil

Michael F. Jackson, University of Manitoba, Canada

*Correspondence: Elizabeth J. Coulson e.coulson@uq.edu.au

Specialty section: This article was submitted to

Neurodegeneration,

a section of the journal

Frontiers in Neuroscience

Received: 05 May 2017

Accepted: 26 July 2017 Published: 08 August 2017

Citation: May LM, Anggono V, Gooch HM, Jang SE, Matusica D, Kerbler GM, Meunier FA, Sah P and Coulson EJ (2017) G-Protein-Coupled Inwardly Rectifying Potassium (GIRK) Channel Activation by the $p 75$ Neurotrophin Receptor Is Required for Amyloid $\beta$

Toxicity. Front. Neurosci. 11:455 doi: 10.3389/fnins.2017.00455 by which this occurs is poorly defined. Here we describe a novel, $A \beta$-triggered apoptotic pathway in which $A \beta$ treatment leads to the upregulation of G-protein activated inwardly rectifying potassium (GIRK/Kir3) channels, causing potassium efflux from neurons and A $\beta$-mediated apoptosis. Although, GIRK channel activity is required for A $\beta$-induced neuronal degeneration, we show that it is not sufficient, with coincident signaling by the p75 neurotrophin receptor (p75 NTR) also required for potassium efflux and cell death. Our results identify a novel role for GIRK channels in mediating apoptosis, and provide a previously missing mechanistic link between the excitotoxicity of $A \beta$ and its ability to trigger cell death pathways, such as that mediated by $\mathrm{p} 75^{\mathrm{NTR}}$. We propose that this death-signaling pathway contributes to the dysfunction of neurons in Alzheimer's disease and is responsible for their eventual degeneration.

Keywords: p75 ${ }^{\mathrm{NTR}}$, amyloid $\beta$, Alzheimer's disease, neurodegeneration, excitotoxicity, potassium flux, Kir3, GIRK channel

\section{INTRODUCTION}

Alzheimer's disease is a progressive neurodegenerative disorder that is characterized by deficits in memory and higher cognitive function. This cognitive decline is due to neurodegeneration, particularly of the hippocampus and entorhinal cortex, and loss of the cholinergic neurons of the basal forebrain. The brains of Alzheimer's disease patients contain deposits of aggregated amyloid $\beta(\mathrm{A} \beta)$, and a substantial body of work supports the hypothesis that $A \beta$ underlies the etiology and pathogenesis of the disease (Hardy and Selkoe, 2002; Ballard et al., 2011). At the cellular level, the 42 amino acid form of $A \beta\left(A \beta_{42}\right)$ readily aggregates into soluble oligomers (Haass and Selkoe, 2007) which can directly contribute to neuronal and synaptic dysfunction and degeneration (Walsh et al., 2002; Haass and Selkoe, 2007; Walsh and Selkoe, 2007; Shankar et al., 2008). These A $\beta$-mediated changes, which include the loss of dendritic spines and neurites (Mucke et al., 2000; Smith et al., 2009; Perez-Cruz et al., 2011), 
have been proposed to cause the cognitive decline, which precedes neuronal death in Alzheimer's disease (Ondrejcak et al., 2010; Palop and Mucke, 2010).

Neuronal degeneration in the context of $A \beta$ is linked to the excitotoxic activities of the peptide, whereby an increase in intracellular calcium induced by $\mathrm{A} \beta$ triggers apoptosis by an ill-defined pathway (Palop et al., 2007). An alternative mechanism of $A \beta$-induced neurodegeneration is via the p75 neurotrophin receptor $\left(\mathrm{p} 75^{\mathrm{NTR}}\right) \cdot \mathrm{p} 75^{\mathrm{NTR}}$ initiates apoptosis in a variety of neurodegenerative conditions, including apoptotic death triggered by oligomeric forms of $\mathrm{A} \beta_{42}$ in vitro (Yang et al., 2008; Coulson et al., 2009) and in animal models of Alzheimer's disease (Sotthibundhu et al., 2008; Knowles et al., 2009; Wang et al., 2011). p75 ${ }^{\text {NTR }}$ is expressed throughout life in basal forebrain cholinergic neurons and is also ectopically upregulated in response to $A \beta$ accumulation in other diseasevulnerable brain areas, such as the cortex and hippocampus (Mufson and Kordower, 1992; Chakravarthy et al., 2010; Perez et al., 2011), and in other excitotoxic disease conditions such as motor neuron disease and epilepsy (Ibanez and Simi, 2012).

Although, the mechanism by which $\mathrm{p} 75^{\mathrm{NTR}}$ mediates cell death triggered by $A \beta$ is unclear (Costantini et al., 2005; Coulson, 2006), we have previously demonstrated that neurotrophin signaling through $\mathrm{p} 75^{\mathrm{NTR}}$ can activate G-protein activated inwardly rectifying potassium (GIRK) channels, triggering a cell death pathway (Coulson et al., 2008). GIRK channels are typically activated by inhibitory neurotransmission, allowing transitory potassium efflux, which lowers the neuronal resting membrane potential and dampens neuronal excitability (Dascal, 1997). Activation of GIRK channels is required for some forms of synaptic plasticity such as long-term potentiation (LTP) (Chung et al., 2009a), and GIRK expression can be regulated by enhanced glutamatergic activation (Chung et al., 2009b). As A $\beta$ is known to cause excitotoxicity at least partially via glutamatergic processes (De Felice et al., 2007; Alberdi et al., 2010), these converging lines of evidence suggest that activation of the p $75^{\mathrm{NTR}}$-GIRK pathway by excitotoxic $A \beta_{42}$ may play a direct role in neuronal degeneration. We therefore investigated whether $A \beta$ treatment of neurons affects GIRK channel expression and activity, and whether the resultant changes lead to neuronal degeneration.

\section{MATERIALS AND METHODS \\ Primary Culture}

All animal procedures were approved by the University of Queensland Animal Ethics Committee. Pregnant C57Bl6 mice were sacrificed and their E18 embryos were removed by Caesarian section. Hippocampal tissue was dissected from each embryonic brain, chopped, and digested with $0.05 \%$ trypsin (Gibco). Neurons were then dissociated by serial trituration, passed through a $40 \mu \mathrm{m}$ filter and resuspended in medium. Neurons were plated on poly-L-lysine-coated tissue culture dishes, coverslips, or $3 \mathrm{~cm}$ MatTek glass-bottom dishes (MatTek Corp) and cultured in medium containing Dulbecco's modified Eagle's medium (DMEM)/Ham's F12 (Gibco), 10\% fetal bovine serum (FBS; JRH Biosciences) and $2 \mathrm{ng} / \mathrm{ml}$ brain-derived neurotrophic factor (BDNF). This medium was then changed the next day to neurobasal medium (Gibco) supplemented with B27 (Gibco) and $2 \mathrm{ng} / \mathrm{ml} \mathrm{BDNF}$, and the cells were cultured for $10-24$ days at $37^{\circ} \mathrm{C}$ and $5 \% \mathrm{CO}_{2}$ with medium changes as required. For short-term, lower density cultures, neurons were plated in DMEM/Ham's F12 medium containing 10\% NeuroCult (StemCell Technologies) and $2 \mathrm{ng} / \mathrm{ml} \mathrm{BDNF}$ (Millipore) in tissue culture dishes coated with $0.1 \mathrm{mg} / \mathrm{ml}$ poly-L-lysine (Sigma).

\section{Treatments}

$\mathrm{A} \beta$ peptides were synthesized using t-Boc chemistry and purified using reverse phase HPLC by Dr. James I. Elliott at Yale University. To prepare $A \beta$ peptides for treatment, both $A \beta_{42}$ and $A \beta_{16}$ were reconstituted in sterile water to $200 \mu \mathrm{M}$ stock solution, incubated overnight at $4^{\circ} \mathrm{C}$ and used at $20 \mu \mathrm{M}$ final concentration in medium or electrophysiological bath solution. Fresh solutions were made for each assay. Co-treatments were added once to neuronal cultures at $t=0$, the time of A $\beta$ treatment, unless otherwise stated. APV (30 $\mu \mathrm{M}$; Sigma) was used to block N-methyl-D-aspartate (NMDA) receptors. TertiapinQ (100 nM; Alomone) was used to block GIRK channel activity. To activate $\mathrm{GABA}_{\mathrm{B}}$ receptors and down-regulate GIRK channels, baclofen (Sigma) was used at $50 \mu \mathrm{M}$. The antagonist CGP55845 (1 $\mu \mathrm{M}$; Tocris) was used to block $\mathrm{GABA}_{\mathrm{B}}$ receptor activity. The metalloprotease inhibitor TAPI-2 $(20 \mu \mathrm{M}$; Calbiochem) was used to prevent cleavage of $\mathrm{p} 75^{\mathrm{NTR}}$; the initial treatment was done at $t=0$ and a second treatment of TAPI-2 was performed $6 \mathrm{~h}$ later. The $\mathrm{c} 29$ peptide used to block p75 ${ }^{\text {NTR }}$ death signaling was a 29 amino acid residue peptide of the juxtamembrane Chopper domain (Coulson et al., 2000; Matusica et al., 2013; KRWNSCKQNK QGANSRPVNQ TPPPEGEKL) fused to a non-naturally occurring protein transduction domain peptide (YARAAARNARA) based on PTD4 (Ho et al., 2001). The control used for c29 was a scrambled version of the peptide (SKGQVCRNQP GQNKPEPANK SWKETPLRN) fused to the transduction domain sequence and a fluorescent indicator (FITC; Matusica et al., 2013). These peptides were also synthesized at Yale University.

\section{A $\beta$ SDS-PAGE and Western Blotting}

To identify the aggregation state of $A \beta$ used in these assays, A $\beta$ peptides were separated by SDS-PAGE and detected by western blotting. HPLC-purified A $\beta$ solution was prepared as described above and samples were mixed with LDS sample loading buffer and loaded onto Nupage precast BisTris gels. SDSPAGE was conducted in Nupage MES or MOPS SDS running buffer, after which proteins were transferred to an Immobilon ${ }^{\circledR}$ membrane (BioRad) in 20\% methanol. Blots were incubated with primary $\mathrm{A} \beta$ antibody (1:500, clone $6 \mathrm{~F} / 3 \mathrm{D}$ to residues 8-17; Dako) followed by horseradish peroxidase-conjugated secondary antibodies in phosphate-buffered saline (PBS) containing 0.05\% Tween 20, after which $A \beta$-immunoreactive bands were visualized with SuperSignal ${ }^{\circledR}$ West Pico or Femto Chemiluminescent Substrate (Thermoscientific), according to the manufacturer's instructions. Blots were exposed to film and developed by X-ray developer. 


\section{Calcium Imaging}

To measure calcium flux, cultured neurons were loaded with the calcium indicator Oregon Green $488^{\circledR}$ BAPTA-1 AM ( $5 \mu \mathrm{M}$; Invitrogen) for $1 \mathrm{~h}$ prior to imaging. They were then washed 3 times with medium and imaged on a Marianas TIRF/FRET/FRAP inverted high-speed imaging fluorescence microscope at $37^{\circ} \mathrm{C}$ and $5 \% \mathrm{CO}_{2}$. Neurons were imaged for $\sim 2$ min to obtain baseline calcium fluorescence, then treated with $\mathrm{A} \beta$ peptides and the NMDA receptor antagonist APV as indicated, before being imaged $5 \mathrm{~min}$ later for $\sim 2 \mathrm{~min}$ (for APV) and/or 15 min later (for $A \beta$ ). Calcium flux was observed in both shortterm and long-term cultures. Although, the short-term cultures were spontaneously active, the synchronous firing of the longterm (21-24 days) cultures facilitated quantification of calcium flux, as a result of which long-term cultures were used for these experiments. Fluorescence values of all cells in the field of view (at least three fields of view per condition) of mature cultures were quantified using Slidebook software, and the data were pooled within each condition and analyzed using one-way analysis of variance (ANOVA).

\section{Surface Biotinylation Assay}

The levels of surface GIRK1 and GIRK2 expression were determined by surface biotinylation assay as described previously (Anggono et al., 2011). Briefly, mouse hippocampal neurons cultured for $12-15$ days were treated with $A \beta_{16}(20 \mu \mathrm{M}), \mathrm{A} \beta_{42}(20$ $\mu \mathrm{M})$, or $\mathrm{A} \beta_{42}(20 \mu \mathrm{M})$ plus baclofen $(50 \mu \mathrm{M})$ for $2 \mathrm{~h}$. Neurons were subsequently washed twice with artificial cerebrospinal fluid (ACSF) containing (in $\mathrm{mM}$ ), $25 \mathrm{HEPES}, 120 \mathrm{NaCl}, 5 \mathrm{KCl}, 2$ $\mathrm{CaCl}_{2}, 2 \mathrm{MgCl}_{2}$, and $30 \mathrm{D}$-glucose, $\mathrm{pH} 7.4$, and incubated with $1 \mathrm{mg} / \mathrm{ml}$ Sulfo-NHS-SS-Biotin (Pierce) for $30 \mathrm{~min}$ on ice. Free biotin was quenched by washing cells twice with ice-cold Trisbuffered saline ( $\mathrm{pH}$ 7.4). Cultures were lyzed and sonicated in RIPA buffer and incubated with Neutravidin beads (Pierce) for $3 \mathrm{~h}$ at $4^{\circ} \mathrm{C}$. Beads were washed three times and eluted with $2 \mathrm{X}$ SDS sample buffer, followed by western blotting analyses using rabbit polyclonal antibodies against GIRK1 (Alomone, APC-005, 1:1,000 or Abcam, ab129182, 1:2,000) and GIRK2 (Alomone, APC-006, 1:500) followed by anti-rabbit HRP-linked secondary antibodies $(1: 10,000)$ from GE Healthcare. Bands were visualized using the ECL detection method and X-ray film. For quantification, total and surface GIRK1/2 levels were normalized to actin, and the data are presented as \% change relative to $A \beta_{16}$.

\section{Electrophysiology}

C57Bl6 mice (3-4 weeks old) were deeply anesthetized using isoflurane inhalation and decapitated. The brain was then quickly removed and submerged in ice-cold, oxygenated ACSF containing (in mM): $87 \mathrm{NaCl}, 25 \mathrm{NaHCO}_{3}, 25$ glucose, 50 sucrose, $2.5 \mathrm{KCl}, 1.2 \mathrm{NaH}_{2} \mathrm{PO}_{4}, 4 \mathrm{MgCl}_{2}, 0.5 \mathrm{CaCl}_{2}, \mathrm{pH} 7.4$. Coronal brain slices $(300 \mu \mathrm{m})$ containing the $\mathrm{CA} 1$ region of the rostral hippocampus were prepared using a vibratome (VT1000S, Leica) and transferred for incubation at $36^{\circ} \mathrm{C}$ for $30 \mathrm{~min}$ in oxygenated ACSF containing (in $\mathrm{mM}$ ): $118 \mathrm{NaCl}$, $25 \mathrm{NaHCO}_{3}, 10$ glucose, $2.5 \mathrm{KCl}, 2.5 \mathrm{CaCl}_{2}, 1.2 \mathrm{NaH}_{2} \mathrm{PO}_{4}$ and $1.3 \mathrm{MgCl}_{2}, \mathrm{pH} 7.4\left(95 \% \mathrm{O}_{2} / 5 \% \mathrm{CO}_{2}\right)$. Slices were then equilibrated to room temperature for at least $30 \mathrm{~min}$, before being transferred to the immersion recording chamber. During recordings, slices were continuously perfused with oxygenated ACSF $\left(95 \% \mathrm{O}_{2} / 5 \% \mathrm{CO}_{2}\right)$ at $34^{\circ} \mathrm{C}$ and secured with a platinum harp strung with parallel nylon threads. The CA1 region was visualized under low magnification using an upright microscope (5x magnification; BX50WI, Olympus) and pyramidal neurons of the CA1 stratum pyramidale layer were observed at high magnification $(40 \mathrm{x})$ using differential interference contrast (DIC) optics combined with infrared illumination. Somatic whole-cell recordings were performed using 3-5 $\mathrm{M} \Omega$ borosilicale pipettes filled with potassium-based internal solution containing (in mM): $135 \mathrm{KMeSO}_{4}, 8 \mathrm{NaCl}, 10$ HEPES, $2 \mathrm{Mg}_{2}$-ATP, $0.3 \mathrm{Na}_{3}$-GTP, 0.1 spermine, 7 phosphocreatine, and 0.3 EGTA ( $\mathrm{pH} 7.3$ with $\mathrm{KOH}$, osmolarity 280-290 mOsm). GABA -receptor mediated slow inhibitory postsynaptic currents (sIPSCs) were recorded from pyramidal neurons in voltage-clamp at a holding potential of $-50 \mathrm{mV}$, and were evoked by the placement of a concentric bipolar stimulating electrode (World Precision Instruments) in the stratum radiatum to stimulate Schaffer collaterals and local $\gamma$-aminobutyric acid (GABA)-expressing interneurons with single pulses or train stimulation $(20 \mathrm{~Hz}$; Scanziani, 2000). Holding currents were monitored and recorded in voltageclamp at a holding potential of $-60 \mathrm{mV}$. $A \beta_{42}(20 \mu \mathrm{M})$, the $\mathrm{GABA}_{\mathrm{B}}$-selective antagonist CGP55845 (1 $\left.\mu \mathrm{M}\right)$, baclofen $(50 \mu \mathrm{M})$, tertiapin (100 nM), 2-amino-5-phosphonopentanoic acid (APV; 50 $\mu \mathrm{M}$ ), and ZD7288 (4-ethylphenylamino-1,2dimethyl-6-methylaminopyrimidinium chloride, $10 \mu \mathrm{M}$ ) were bath applied where indicated. During $\mathrm{GABA}_{\mathrm{B}}$ recordings, picrotoxin $(50 \mu \mathrm{M})$ was added to the perfusing ACSF solution to block ionotropic $\mathrm{GABA}_{\mathrm{A}}$ receptors. Signals were amplified using a Multiclamp 700B amplifier (Molecular Devices), current signals were filtered at $4-8 \mathrm{kHz}$, digitized at $20 \mathrm{kHz}$ using an Instrutech ITC-18 interface, and acquired on an iMac using Axograph X. Access resistance (4-18 $\mathrm{M} \Omega$, uncompensated) was monitored throughout the experiment. Modulation of the GIRK current reversal potential by high external potassium was performed using primary hippocampal cultures, prepared as described above, and the osmolarity of high $\mathrm{KCl}(20$ $\mathrm{mM}$ ) ACSF was balanced by an equivalent reduction in $\mathrm{NaCl}$ molarity.

\section{Potassium Imaging}

To quantify change in the intracellular potassium concentration, neurons that had been cultured for 3 days were incubated with $2 \mu \mathrm{M}$ Asante Potassium Green-2 (Teflabs) indicator for $30 \mathrm{~min}$. After exchange of the medium, cultures were left to recover for a minimum of $15 \mathrm{~min}$ in an incubator before being transferred to the Axio observer microscope chamber held at $37^{\circ} \mathrm{C}$ and $5 \% \mathrm{CO}_{2}$. Fluorescence $(488 \mathrm{~nm})$ and DIC (Nomarski) images were captured every $5 \mathrm{~min}$ for $3 \mathrm{~h}$. Test compounds, including $\mathrm{A} \beta_{42}$, were added $15 \mathrm{~min}$ after imaging had commenced. The fluorescence values of all cells in the field of view (six fields of view per condition) were quantified using Imaris software from images taken 5 min before the addition of the test compounds (time 1) and 30,110 , or $160 \mathrm{~min}$ after treatment (time 2). The percentage change in fluorescence over time for each cell was then calculated. 


\section{In vitro Apoptosome Assay}

Apoptosome components were isolated from the soluble fraction of cell lysates obtained from nerve growth factor (NGF)differentiated PC12 cells. PC12 cells were maintained at $37^{\circ} \mathrm{C}$ with $10 \% \mathrm{CO}_{2}$ in DMEM supplemented with $10 \%$ horse serum (Sigma) and 5\% FBS before being differentiated with $50 \mathrm{ng} / \mathrm{ml}$ NGF in DMEM supplemented with $0.1 \%$ horse serum for 2 days. They were then collected by scraping, washed with ice cold PBS, and centrifuged to form tight cell pellets which were weighed and resuspended 1:1 with hypotonic extraction buffer containing (in mM): 5 EGTA, 50 PIPES, $2 \mathrm{MgCl}_{2}$, 1 DTT, 0.1 PMSF, pH 7. Cells were allowed to swell on ice for $25 \mathrm{~min}$ before being sheared with 100 strokes of a B-type pestle in a Dounce homogenizer (Kimble-Kontes). The solution was centrifuged at 100,000 $\mathrm{g}$ for $1 \mathrm{~h}$ at $4^{\circ} \mathrm{C}$, after which the supernatant was aliquoted and stored immediately at $-80^{\circ} \mathrm{C}$. Lysate containing $100 \mu \mathrm{g}$ protein was incubated in a $50 \mu \mathrm{l}$ reaction mix with cytochrome C $(0$, $0.5,1.0,1.5$, or $2 \mu \mathrm{M}), 0.5 \mu \mathrm{M}$ dATPs, and the fluorescent caspase substrate Ac-DEVD-AMC $(100 \mu \mathrm{M})$, with $\mathrm{KCl}$ added to a concentration of $20,50,80,110$, or $140 \mathrm{mM}$. All conditions were assessed in triplicate. Cleavage of the substrate was measured by a Polarstar Optima plate reader every $5 \mathrm{~min}$ for $1 \mathrm{~h}$ (excitation filter, $380 \pm 10 \mathrm{~nm}$; emission filter, $460 \mathrm{~nm}$ ); triplicate readings were pooled for each condition.

\section{Neurite Outgrowth Assay}

Neurons were plated at a density of 40,000 cells per well of a 24 -well plate (Falcon) and grown for $\sim 3$ weeks. They were then treated with $A \beta$, baclofen and/or CGP55845. After $20 \mathrm{~h}$, neurons were washed, fixed with $4 \%$ paraformaldehyde, immunostained for $\beta$-III tubulin and co-stained with DAPI. Three random fields of view were imaged for each condition per experiment; images were overlaid with a grid and the neurite crossings were counted and divided by the number of neurons per field (DAPI- and $\beta$ III tubulin-positive soma) to give a ratio of neurites per neuron. Ratios were averaged across conditions and data were analyzed by one-way ANOVA.

\section{In vitro Neuronal Survival Assays}

To determine the level of neuronal survival, low density hippocampal cultures were plated at 40,000 cells per $11 \mathrm{~mm}$ diameter well of a 4 -well plate (Cell-star ${ }^{\circledR}$, Greiner) with a grid marked for later cell identification. Cells were cultured overnight in growth medium at $37^{\circ} \mathrm{C}$ and $5 \% \mathrm{CO}_{2}$. The number of neurons within a fixed grid quadrant was counted $24 \mathrm{~h}$ after plating $(t=0)$ and the same quadrant was counted again $20 \mathrm{~h}$ later $(t=20)$. Live cells were determined by morphology, and, in some experiments, also by exclusion of propidium iodide. Similar results were obtained when MTT [3-(4,5-dimethylthiazol-2-yl)2,5-diphenyltetrazolium bromide] was used to identify live cells in the cultures. All treatments were applied immediately after the initial cell count and remained in the culture medium until the end of the experiment. Survival was expressed as the percentage of neurons remaining alive at $t=20$. Under each condition a minimum of 250 neurons to a maximum of 600 neurons were counted across 4 different gridded wells at $t=0$. Each condition was replicated a minimum of 3 times $(N=3)$, with neurons derived from different litters on different days.

\section{p75 ${ }^{\text {NTR }}$ Cleavage Experiments}

p $75^{\mathrm{NTR}}$ - and TrkB-expressing NSC-34 cells were grown to $60 \%$ confluence in T25 flasks at a density of $5 \times 10^{7}$ cells/flask in DMEM supplemented with 10\% FBS and 1\% penicillin/streptomycin/glutamine solution (PSG) at $37^{\circ} \mathrm{C}$ and $5 \% \mathrm{CO}_{2}$, on a poly-D-lysine $(100 \mu \mathrm{g} / \mathrm{ml})$ and rat-tail collagen $(50 \mu \mathrm{g} / \mathrm{ml})$ matrix, supplemented with $2 \mu \mathrm{g}$ of laminin. Cells were differentiated by exchange of medium to 1:1 DMEM:Ham's F12, plus 1\% N-2 supplement, 1\% PSG, 1\% modified Eagle's medium non-essential amino acids, and $1 \mu \mathrm{M}$ retinoic acid for 3 days. Cells were then treated with $20 \mu \mathrm{M} \mathrm{A} \beta_{42}$ or $20 \mu \mathrm{M} \mathrm{A} \beta_{16}$ either alone or in combination with the TAPI compound for $3 \mathrm{~h}$. To inhibit degradation of the $\mathrm{p} 75^{\mathrm{NTR}}$ intracellular domain fragment cells were treated with $5 \mu \mathrm{M}$ clasto-lactacystin $\beta$ lactone (Calbiochem) and $1 \mu \mathrm{M}$ epoxomicin (Sigma) $1 \mathrm{~h}$ prior to addition of other compounds. Cells were treated with $200 \mathrm{nM}$ of phorbol 12-myristate 13-acetate (PMA; Sigma) as a positive control for $\mathrm{p} 75^{\mathrm{NTR}}$ cleavage. They were then lyzed using chilled lysis buffer containing $10 \mathrm{mM}$ Tris- $\mathrm{HCl}, \mathrm{pH} 8.0,150 \mathrm{mM} \mathrm{NaCl}, 2$ mM EDTA, 1\% NP-40, 1\% Triton X-100, 10\% glycerol, $1 \mathrm{mM}$ phenylmethanesulfonyl fluoride, $1 \mathrm{mM}$ sodium orthovanadate, $1 \mu \mathrm{M}$ batimastat (BB-94), and $1 \%$ Roche protease inhibitor cocktail. Following electrophoresis of cell lysates through 4$12 \%$ Bis-Tris buffered SDS gels (Life Sciences), the following antibodies were used for western blotting: rabbit anti-p $75^{\mathrm{NTR}}$ intracellular domain \#9992 (1:5,000; a kind gift from Prof Moses Chao, Skirball Institute), mouse anti- $\beta$-III tubulin $(1: 1,000$; Promega), and LICOR donkey anti-rabbit 680 or donkey antimouse 800 secondary antibody (1:50,000; Invitrogen). Blots were visualized with Supersignal West Femto Sensitivity Substrate (Pierce).

\section{Statistical Analysis}

Statistical analyses were performed using Prism 4 for Macintosh (GraphPad Software, Inc.). Two group comparisons were made using $t$-tests. For multiple comparisons, data were analyzed by ANOVA conducted using Newman-Keuls posttest comparisons, except for the potassium imaging data which were analyzed using Tukey's multiple comparisons post-test. All graphs are mean \pm SEM.

\section{RESULTS}

\section{A $\beta$ Upregulates GIRK Channel Surface Expression and Activity}

We first prepared a solution of $\mathrm{A} \beta_{42}$ that contained predominantly low-order oligomers and monomers (Figures 1A,B). Treatment of cultured embryonic mouse hippocampal neurons with $20 \mu \mathrm{M} \mathrm{A} \beta_{42}$, but not the control $\mathrm{A} \beta_{16}$ peptide, raised the neuronal intracellular calcium concentration (Figure 1C), indicating that it had excitotoxic properties. Furthermore, the calcium increase induced by $A \beta_{42}$ occurred most obvious in spontaneously active neuronal cultures (data not shown) and was inhibited by the NMDA receptor antagonist 
A

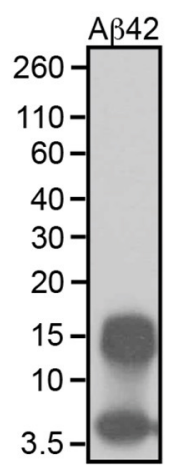

D

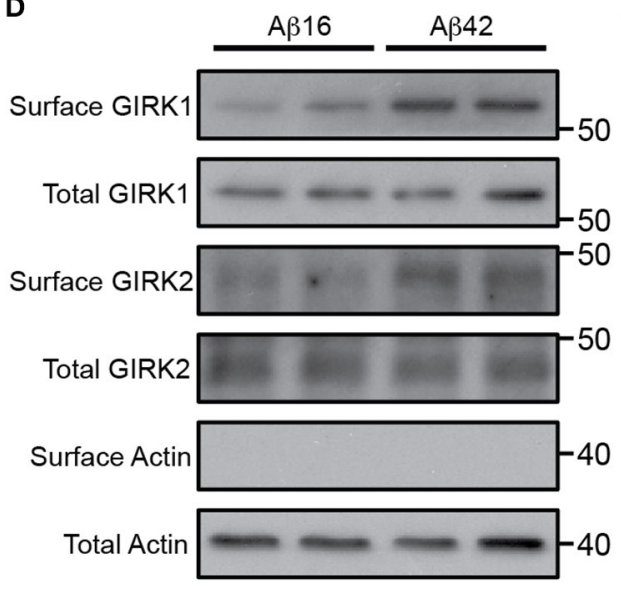

B

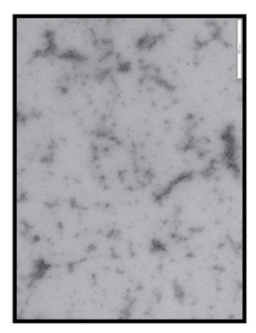

C

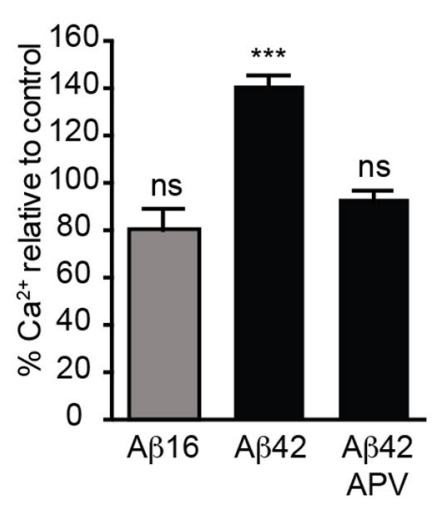

E

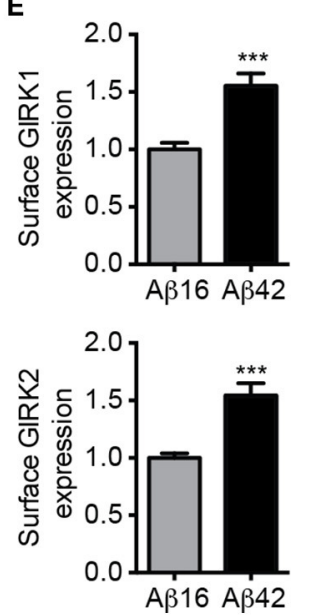

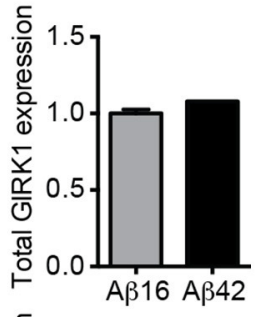

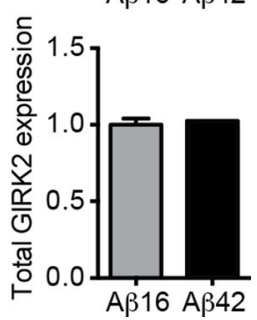

FIGURE 1 | Excitotoxic oligomeric $A \beta_{42}$ upregulates GIRK channel surface expression. (A) Western blot of the preparation of purified $A \beta_{42}$ peptide used in this study demonstrating that it is predominantly in an oligomeric $(15 \mathrm{kDa})$ or monomeric $(4 \mathrm{kDa})$ form. (B) $A$ transmission electron photomicrograph of the $A \beta_{42}$ peptide preparation. (C) Quantification of relative $\left[\mathrm{Ca}^{2+}\right]_{i}$ of spontaneously active cultured neurons following treatment with $A \beta_{16}, A \beta_{42}$, or $A \beta_{42}$ and the NMDA receptor antagonist APV as indicated. The fluorescence intensity of the Oregon Green 488 BAPTA -AM almost doubled in neurons treated with A $\beta_{42}$ in comparison to the untreated baseline ( $n=59$ neurons). Pre-treatment with the NMDA receptor inhibitor APV prevented the A $\beta_{42}$-induced calcium increase $\left(n=69\right.$ neurons, ${ }^{\star \star \star} p<$ 0.001), with calcium levels being similar to those of controls. Western blot (D) and quantification (E) of total and surface GIRK1 and GIRK2 protein levels in hippocampal neurons treated for $2 \mathrm{~h}$ with either control $A \beta_{16}$ or oligomeric $A \beta_{42}\left(n=12\right.$ replicates; ${ }^{\star * \star} p<0.001$; Mann-Whitney $U$-test).

APV (Figure 1C), indicating glutamate receptor activity was required for the excitotoxicity. As it has been shown that over-activation of the NMDA receptor increases the number of GIRK channels at the surface of neurons (Chung et al., $2009 \mathrm{~b})$, we investigated the effect of $\mathrm{A} \beta_{42}$ on GIRK channel expression in cultured embryonic mouse hippocampal neurons. Western blot analysis demonstrated that surface GIRK1 and 2 protein levels were significantly increased in neurons $2 \mathrm{~h}$ after $\mathrm{A} \beta_{42}$, but not control $\mathrm{A} \beta_{16}$, application (Figures 1D,E). Total cellular levels of GIRK1 and 2 subunits were unchanged by the treatments (Figures 1D,E). These data indicate that $\mathrm{A} \beta_{42}$ causes a rapid redistribution of existing GIRK subunits into the plasma membrane.

The functional effect on basal GIRK channel activity of the $A \beta_{42}$-induced increase in membrane GIRK subunits was examined in acute brain slices using whole-cell voltage-clamp recordings from CA1 pyramidal neurons. Bath application of $\mathrm{A} \beta_{42}$ led to a slowly developing outward current when the cells were voltage-clamped at resting membrane potentials $(69 \pm 27$ pA, $n=6 / 7$; Figures 2A,B), analogous to that induced by an acute treatment with baclofen, a $\mathrm{GABA}_{\mathrm{B}}$ receptor agonist that activates GIRK channels ( $97 \pm 18 \mathrm{pA}, n=5)$. This $\mathrm{A} \beta_{42}$-induced outward current was induced within $5 \mathrm{~min}$ of application, indicating that GIRK channel upregulation occurred relatively quickly in response to $A \beta_{42}$ treatment. Following $A \beta_{42}$ treatment, a number of neurons became hyperpolarized, indicating efflux of potassium (data not shown). The effect of $A \beta_{42}$ on holding currents was blocked by prior incubation in the presence of the potassium channel blocker barium $\left(\mathrm{BaCl}_{2}+\mathrm{A} \beta_{42},-7.4 \pm 4.9\right.$ pA, $\left.n=2 ; \mathrm{BaCl}_{2},-50.5 \pm 8.8 \mathrm{pA}, n=5\right)$. It was also blocked by tertiapin ( $>30$ min incubation, $-5 \pm 3 \mathrm{pA}, n=4$ ), the NMDA receptor antagonist APV $(-14 \pm 6 \mathrm{pA}, n=4)$ or tertiapin plus APV combined $(-4 \pm 11 \mathrm{pA}, n=4$; Figures $2 \mathrm{~A}, \mathbf{B})$.

We next investigated the effect of acute $A \beta_{42}$-induced upregulation of GIRK channels on hippocampal circuit activity via synaptically evoked $\mathrm{GABA}_{B}$ GIRK currents within the 
A

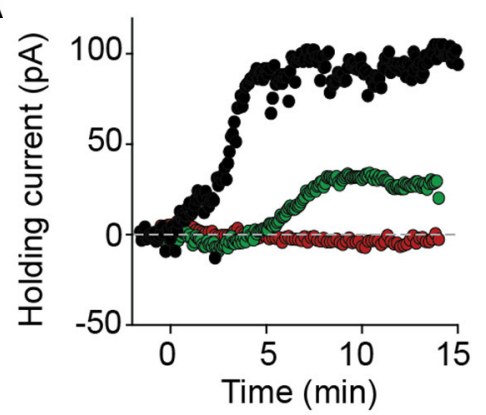

C

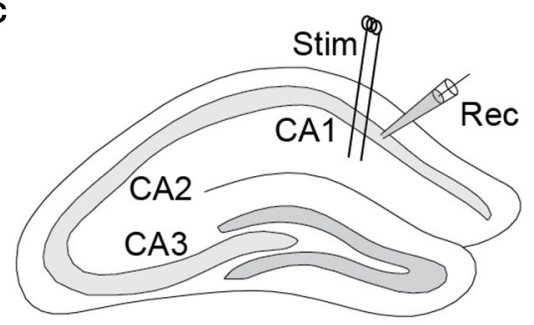

$\mathbf{E}$

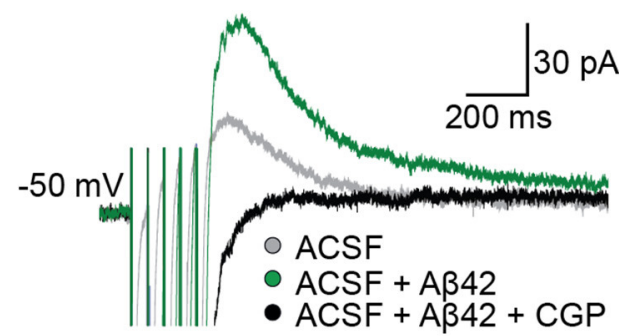

B
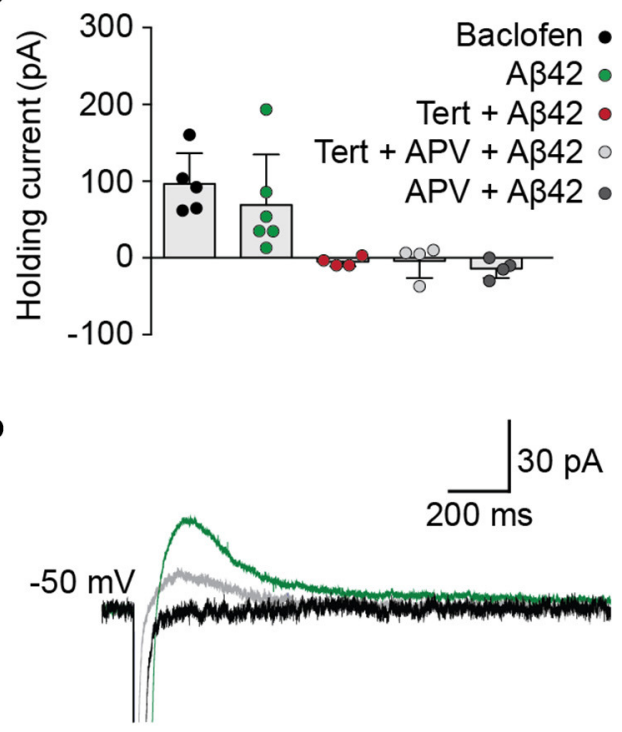

$\mathbf{F}$

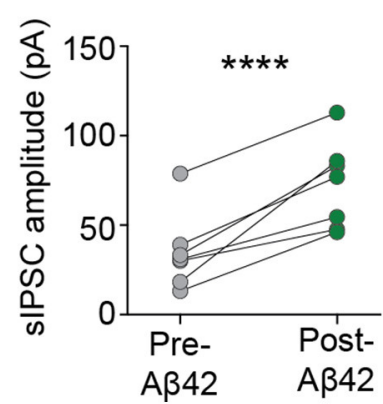

FIGURE 2 | $A \beta_{42}$ upregulates GIRK channel activity. (A) Bath application of $A \beta_{42}(20 \mu \mathrm{M})$ at time $=0$ evoked an outward current in CA1 pyramidal cells (green trace), analogous with the GABA $\mathrm{B}_{B}$ receptor agonist baclofen $\left(50 \mu \mathrm{M}\right.$; black trace), when recorded in voltage-clamp at holding potential $-60 \mathrm{mV}$. $A \beta_{42-}$ induced efflux was not observed in cells previously incubated in the specific GIRK channel antagonist tertiapin (100 nM; red trace). (B) Summary plot to show changes in averaged holding current from single cells $15 \mathrm{~min}$ after the application of baclofen ( $97 \pm 18 \mathrm{pA}, n=5$; black), A $\beta_{42}$ ( $69 \pm 27 \mathrm{pA}, n=6 / 7$ cells; green), tertiapin-incubated A $\beta_{42}$ application ( $-5 \pm 3 \mathrm{pA}, n=4$ cells; red), tertiapin- and APV-incubated $\mathrm{A} \beta_{42}$ application ( $-5 \pm 11 \mathrm{pA}, n=4$ cells; light gray) and APV-incubated A $\beta_{42}$ application ( $-14 \pm 6 \mathrm{pA}, n=4$; dark gray). (C) Schematic representation indicating electrode placements used to evoke (Stim) and record (Rec) slow inhibitory postsynaptic currents (SIPSCs) within coronally sectioned hippocampal tissue. Representative single-pulse (D) and train-stimulated (20 Hz; E) sIPSC traces before (gray) and after (green) application of bath applied $A \beta_{42}(20 \mu \mathrm{M})$, blocked by GABA receptor antagonist CGP55845 (1 $\mu \mathrm{M}$; black), recorded at a holding potential of $-50 \mathrm{mV}$. (F) Summary plot of averaged sIPSC peak amplitude responses for all tested CA1 pyramidal neurons, before and after bath application of A $\beta_{42}$ (one-way ANOVA, Bonferroni test, ${ }^{\star \star \star \star} p<0.0001, n=7$ ).

hippocmapus. In the presence of picrotoxin to block $\mathrm{GABA}_{\mathrm{A}}$ receptor-mediated synaptic currents, electrical stimulation of the Schaffer collaterals generated slow IPSCs in CA1 hippocampal neurons when voltage-clamped at a holding potential of -50 $\mathrm{mV}$ (Figure 2C). Bath application of $\mathrm{A} \beta_{42}$ significantly increased the amplitude of sIPSCs (green trace; one-way ANOVA, Bonferroni test, $p<0.0001, n=7$; Figures 2D-F), which were completely blocked by bath application of the $\mathrm{GABA}_{\mathrm{B}}$ selective antagonist CGP55845 ( $1 \mu \mathrm{M}$; Figures 2D-F). This effect on the synaptically evoked GIRK currents was observed from as early as $8 \mathrm{~min}$ after $A \beta_{42}$ application and was sustained for the duration of the recording (up to $40 \mathrm{~min}$ ). These data indicate that synaptically activated GIRK channel currents are upregulated following $A \beta_{42}$ treatment, leading to enhanced slow inhibitory neurotransmission in the CAI hippocampal circuit.

\section{GIRK Channel Activity Results in Lowered Intracellular Potassium}

We next asked if significant potassium efflux occurred via potassium channels following $\mathrm{A} \beta$ treatment by measuring the intracellular potassium concentration using a fluorescent indicator APG-2. APG-2 fluorescence declined over time in all conditions over the course of $160 \mathrm{~min}$, likely due to potassium efflux through leak channels (Figure 3A). However, the intracellular fluorescence of $\mathrm{A} \beta_{42}$-treated neurons significantly decreased compared to that of $A \beta_{16}$-treated neurons (Figure 3A), indicating a considerable loss of intracellular potassium in the 


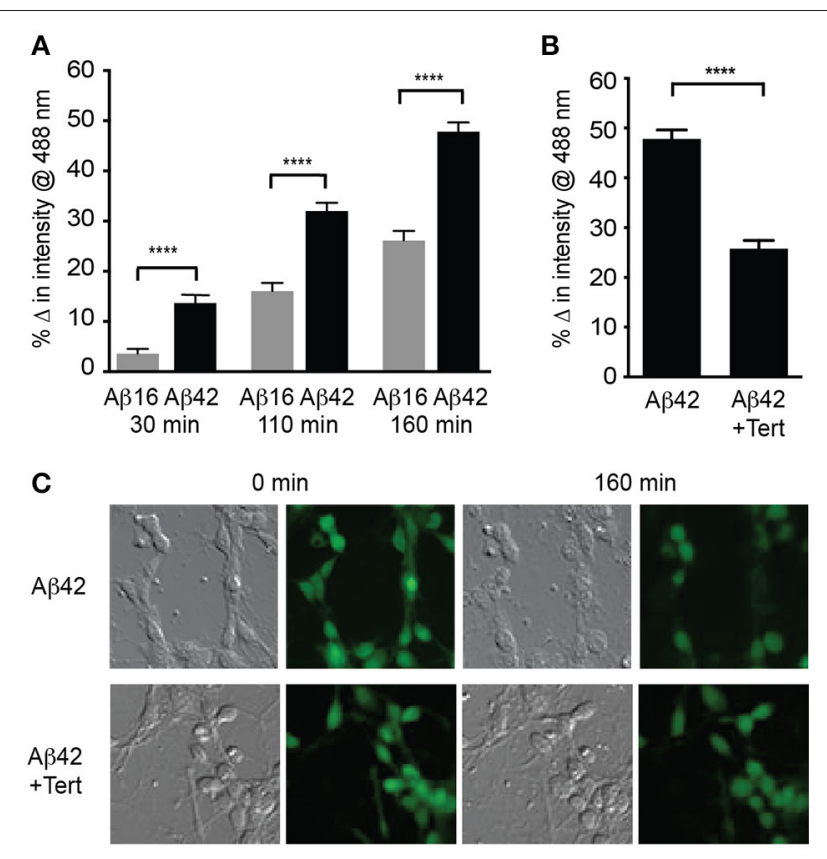

D

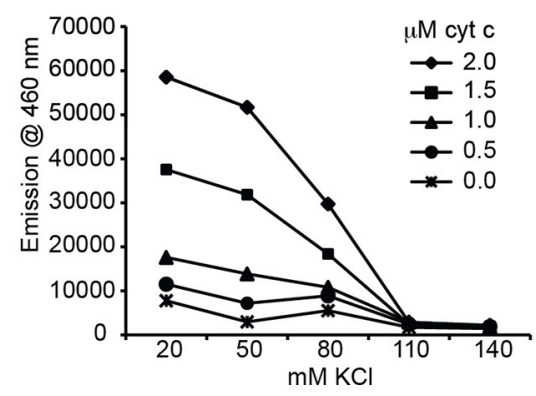

FIGURE 3 | GIRK channel activity results in lowered intracellular potassium, a prerequisite for apoptosome activity. (A) Average decrease in potassium concentration within individual cultured hippocampal neurons, as measured by the fluorescence of the potassium indicator Asante Potassium Green-2 at each of the indicated times after $A \beta$ application ( $n=502$ cells; ${ }^{\star \star \star \star} p<0.0001$ ). (B) Average potassium concentration decrease in cultured neurons treated with $A \beta_{42}$ and the GIRK channel inhibitor tertiapin (Tert) for $160 \mathrm{~min}$ ( $n=538$ neurons; $\left.{ }^{* \star * *} p<0.0001\right)$. (C) Representative relief contrast and fluorescence (Asante Potassium Green-2) photographs of neuronal cultures taken immediately and 160 min after $A \beta$ and tertiapin treatment. (D) Graph of caspase activity, detected by cleavage of the fluorogenic substrate Ac-DEVD-AMC (emission at $460 \mathrm{~nm}$ ), in lysates of NGF-differentiated PC12 cells added to different concentrations of $\mathrm{KCl}$ buffers $\left(\mathrm{K}^{+}\right.$concentration ranging from 20 to $140 \mathrm{mM}$ ), and incubated in the presence of a range of cytochrome c concentrations $(0-2 \mu \mathrm{M})$. Neuronal physiological $\mathrm{K}^{+}$

concentrations (>110 mM) completely suppressed caspase activity regardless of cytochrome c concentration, and maximal caspase activity occurred in the lowest $(20 \mathrm{mM}) \mathrm{K}^{+}$concentration. Cytochrome c concentrations higher than 1 $\mu \mathrm{M}$ combined with $\mathrm{K}^{+}$concentrations lower than $80 \mathrm{mM}$ allowed caspase activity to occur (data points are the average of triplicates; all non-overlapping data points at these concentrations are significantly different at $p \leq 0.01$ ).

former condition. As it has been determined that the APG-2 fluorescence is saturated at potassium concentrations higher than $\sim 80 \mathrm{mM}$ (Rimmele and Chatton, 2014), this result indicates that the internal potassium concentration of many of the $A \beta_{42}$-treated neurons was falling below $80 \mathrm{mM}$. To determine whether the potassium efflux might be mediated via GIRK channels, neurons were treated with the most specific GIRK channel inhibitor, tertiapin, which significantly inhibited the $A \beta_{42}$-induced reduction in intracellular potassium (Figures 3B,C).

Activation of caspases by the apoptosome can be regulated by potassium levels (Yu and Choi, 2000; Cain et al., 2001; Coulson et al., 2008). To examine whether the reduced level of intracellular potassium in the neurons treated with $\mathrm{A} \beta$ was capable of mediating caspase activation, we determined the relationship between potassium concentration and apoptosome formation. This was achieved by using a cell-free assay in which the core mitochondrial cell death machinery of the apoptosome, comprising cytochrome c, caspase 9, and Apaf1 (Riedl and Salvesen, 2007), was derived from cell lysates. The ability of these components to form an apoptosome and cleave a fluorogenic caspase 3 substrate was measured in decreasing concentrations of potassium buffer and increasing concentrations of exogenous cytochrome c. Physiological levels of potassium (110-140 mM; Yu and Choi, 2000) were able to prevent all apoptosome activity regardless of the cytochrome $c$ concentration (Figure 3D). By contrast, $80 \mathrm{mM}$ potassium or less resulted in significant caspase activity, indicating permissiveness for apoptosome formation (Figure 3D). These in vitro assays demonstrated that a potassium concentration approaching half that typically found in healthy neurons, and equivalent to that induced in $\mathrm{A} \beta_{42}$-treated neurons, is necessary for activation of the apoptosome by cytochrome $\mathrm{c}$, which in turn is a prerequisite for apoptosis via the mitochondrial cell death pathway (Cain et al., 2001).

\section{GIRK Channel Activity Is Required for $A \beta_{42}$-Induced Neuronal Degeneration}

We next treated neuronal cultures with $A \beta$ overnight, finding that $A \beta_{42}$ but not $A \beta_{16}$ treatment induced significant neurite degeneration as well as the death of more than $60 \%$ of neurons, with degenerative changes being observed after $5 \mathrm{~h}$ of treatment (Figure 4A).

We then asked whether potassium efflux was required for $\mathrm{A} \beta$-induced toxicity by increasing the extracellular potassium concentration in the culture medium from the normal 5-25 $\mathrm{mM}$. First, we recorded from cultured hippocampal neurons and found that raising the level of extracellular potassium shifted the reversal potential of the GIRK current from $-93 \pm 4$ to -36 $\pm 2.2 \mathrm{mV}(n=4)$. With the same change in potassium, the resting membrane potential depolarized from $-81 \pm 4$ to -40 $\pm 2 \mathrm{mV}$. Importantly, the resting membrane potential shifted from being more positive than the equilibrium potential for potassium to being close to this equilibrium potential. Using the measured current-voltage relationships, the expected GIRK current at the resting membrane potential in low potassium was $+21.2 \pm 10 \mathrm{pA}$ whereas in high potassium it was -9.6 $\pm 8.9 \mathrm{pA}$, i.e., there was virtually no outward current. We then raised the extracellular potassium concentration in the culture medium and found that it inhibited $A \beta$-induced death of neurons (Figure 4B). Similarly, blocking GIRK channels with the GIRK channel inhibitor tertiapin which significantly inhibited the $\mathrm{A} \beta_{42}$-induced potassium efflux (Figure 3B), also inhibited neuronal death (Figures 4A,C). 

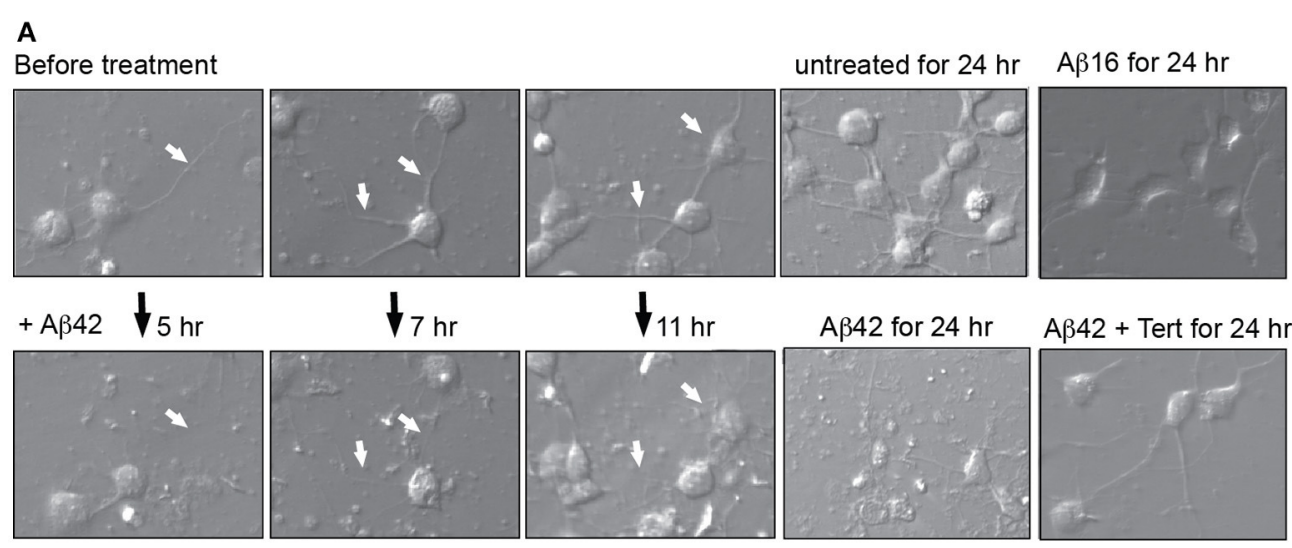

A 342 for $24 \mathrm{hr}$

$\mathrm{A} \beta 42+$ Tert for $24 \mathrm{hr}$

B

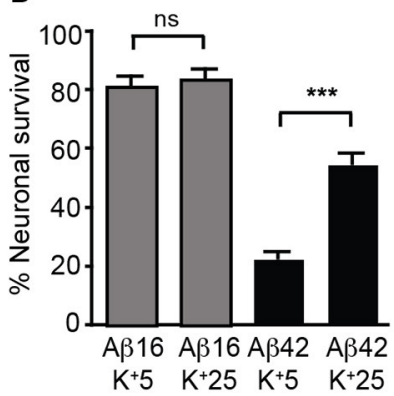

C

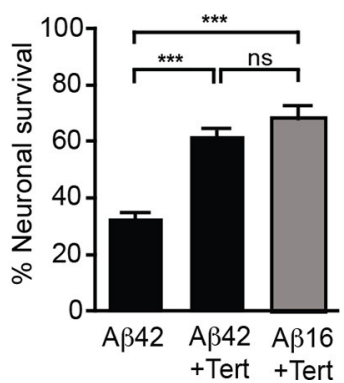

FIGURE 4 | GIRK channel activity is required for $A \beta_{42}$-induced neuronal death. (A) Images of neuronal degeneration in hippocampal cultures that were treated with $A \beta_{42}$ or $A \beta_{16} 24 \mathrm{~h}$ after culture establishment. Neurites (highlighted by white arrows) showed considerable degeneration within $5 \mathrm{~h}$ of $A \beta_{42}$ application with obvious neurite loss and some blebbing as early as $7 \mathrm{~h}$ after $A \beta_{42}$ treatment. Neurons that had established extensive neuritic networks prior to treatment also showed neuritic loss and blebbing $11 \mathrm{~h}$ after $A \beta_{42}$ application. Neurons cultured for $24 \mathrm{~h}$ without $A \beta$ (untreated) or in the presence of $A \beta_{16}$ developed healthy neuritic networks. Treatment of cultured neurons with $A \beta_{42}$ for $24 \mathrm{~h}$ resulted in neuronal loss, with most surviving neurons displaying apoptotic morphology. In contrast, fewer cells displayed degenerative morphological changes in $A \beta_{42}$-treated cultures with co-application of tertiapin (Tert) (B) Percentage survival of neurons cultured in the presence of $A \beta$ in either typical potassium concentrations $\left(5 \mathrm{mM} ; \mathrm{K}^{+} 5\right)$, or high potassium $\left(25 \mathrm{mM}\right.$; $\left.\mathrm{K}^{+} 25\right)$ for $20 \mathrm{~h}$; the latter condition inhibited intracellular potassium efflux from cells. $A \beta_{42}$-initiated neuronal death was inhibited in the presence of $25 \mathrm{mM}$ potassium ( $N=3$ experiments). (C) Percentage survival of neurons cultured in the presence of $A \beta$ and tertiapin (Tert) for $20 \mathrm{~h}$. A $\beta_{42}$-initiated neuronal death was inhibited when GIRK channels were blocked with tertiapin ( $N=6$ experiments).

${ }^{* * *} p<0.001$, ns, not significant.

We therefore asked whether increased surface expression and activity of GIRK channels was a requirement for this $A \beta$-induced neurotoxicity. We reasoned that sustained stimulation of $G_{A B A}$ receptors, which are tightly coupled to GIRK channels, may lead to channel desensitization, and/or endocytosis and degradation of the entire receptor-channel complex, such as occurs for similar receptor-channel complexes (Clancy et al., 2007; Fowler et al., 2007; Raveh et al., 2010). Consistent with this idea, we found that a chronic $2 \mathrm{~h}$ treatment of cultured neurons with the $\mathrm{GABA}_{\mathrm{B}}$ agonist baclofen reversed the upregulation of GIRK1 and 2 subunits on the surface of neurons induced by $A \beta$ treatment, without changing the total GIRK subunit level (Figures 5A,B). Chronic baclofen treatment also inhibited the loss of potassium from $\mathrm{A} \beta$-treated cells (Figures 5C,D). Furthermore, baclofen treatment significantly inhibited neuronal degeneration in longterm cultures (Figures 5E,F) and neuronal death (Figure 5G) induced by $A \beta_{42}$ over $24 \mathrm{~h}$ in short-term cultures.

Taken together, these results indicate that potassium efflux through GIRK channels is a major mediator of $\mathrm{A} \beta_{42}$-induced neurotoxicity in hippocampal cultures and suggests that $A \beta$ induces the upregulation of GIRK channel activity, thereby resulting in potassium efflux, reduced intracellular potassium, and apoptosis.

\section{Death Signaling Is Mediated by $p 75^{\text {NTR }}$ Signals}

Despite an increase in GIRK channels at the cell surface, their typical activation by neurotransmitter-mediated $G \beta \gamma$ (e.g., following activation of $\mathrm{GABA}_{\mathrm{B}}$ receptors) does not lead to a sustained potassium efflux or the lowering of intracellular potassium levels sufficient to promote cell death (see Section Discussion). However, we have previously demonstrated that $\mathrm{p} 75^{\mathrm{NTR}}$ can cause pathological activation of GIRK channels via upregulation of $\mathrm{PIP}_{2}$ levels (Coulson et al., 2008), which does not require $G \beta \gamma$ and which is necessary and sufficient for GIRK channel activation (Zhang et al., 1997; Huang et al., 1998). Furthermore, several groups, including ours, have reported a key role for $\mathrm{p} 75^{\mathrm{NTR}}$ in $\mathrm{A} \beta$-induced neuronal degeneration (Sotthibundhu et al., 2008; Yang et al., 2008). 
A

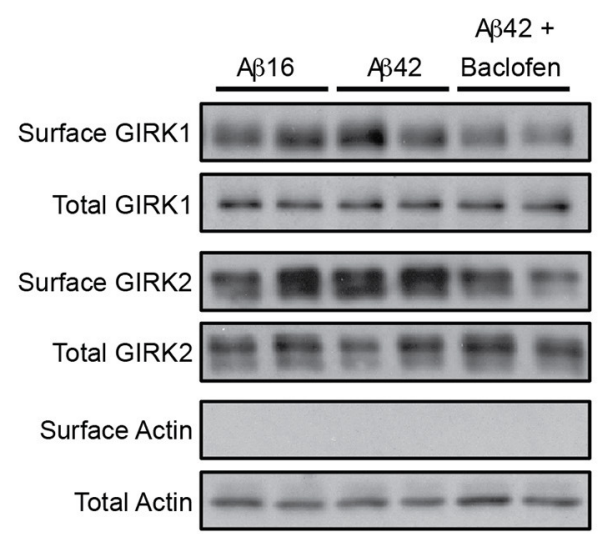

C

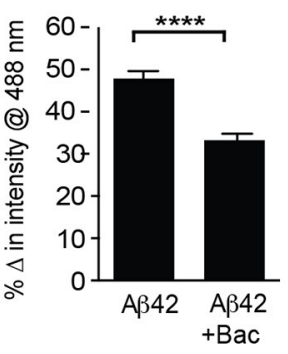

B
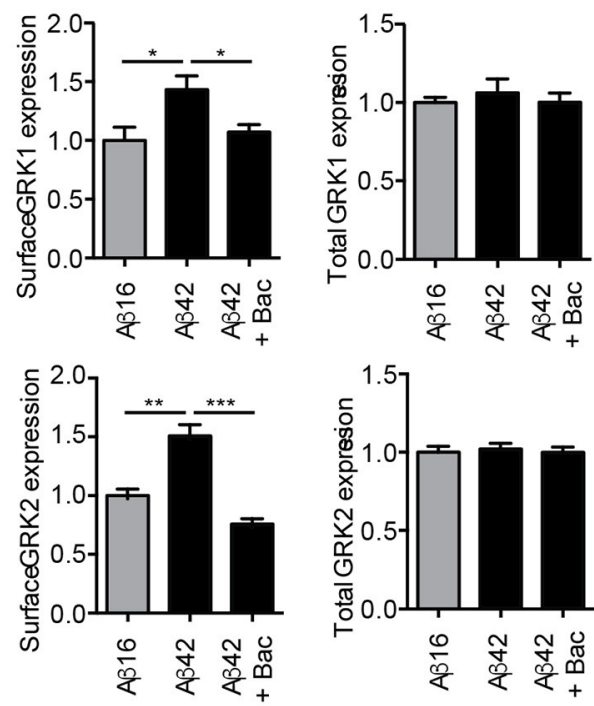

0 min

$160 \mathrm{~min}$
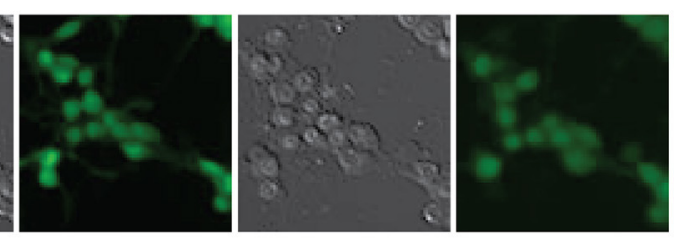

E A $\beta 16$

A 342

$A \beta 42+B a c$

$A \beta 42+B a c+C G P$
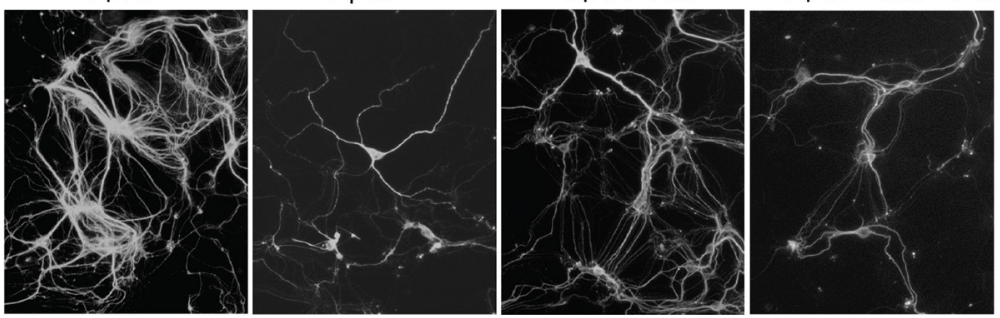

F
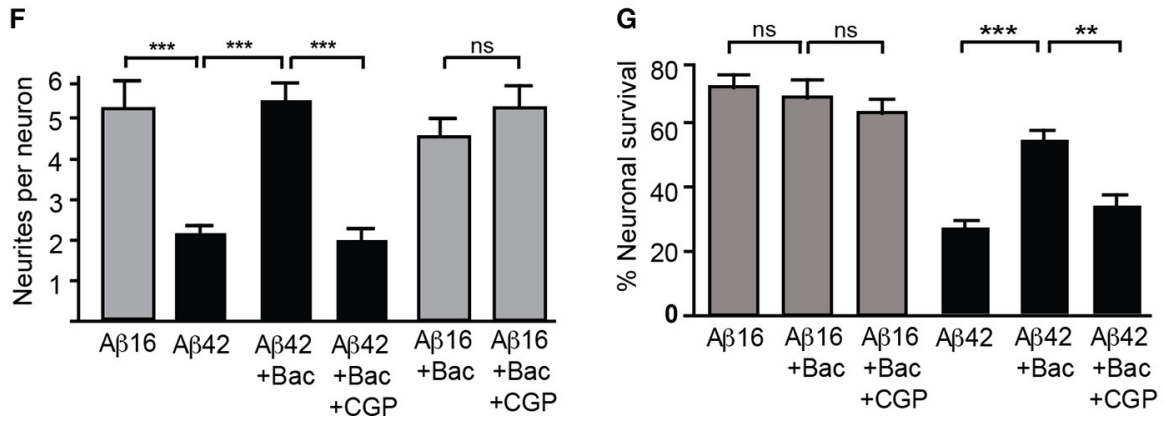

FIGURE 5 | GIRK channel down-regulation inhibits $A \beta_{42}$-induced neuronal degeneration. Western blots (A) and quantification (B) of total and surface GIRK1 and GIRK2 protein levels in mature hippocampal neurons treated for $2 \mathrm{~h}$ with either control $\mathrm{A} \beta_{16}$ or oligomeric $\mathrm{A} \beta_{42}$ and baclofen ( $N=4$ experiments). Baclofen treatment reversed the $A \beta$-induced upregulation of surface GIRK channel subunits. (C) Potassium loss from cultured neurons treated with $A \beta_{42}$ was reduced by co-treatment with baclofen ( $n=443$ neurons). (D) Representative relief contrast and fluorescence (Asante Potassium Green-2) photographs of neuronal cultures taken immediately and 160 min after $A \beta$ and baclofen treatment. (E) Photomicrographs of hippocampal cultures immunostained for $\beta$-III tubulin $20 \mathrm{~h}$ after treatment with $A \beta$ peptides, baclofen (Bac) and/or the GABA $A_{B}$ receptor antagonist CGP55845 (CPGt). (F) Quantification of neurite integrity of the treated cultures ( $N=3$ experiments). (G) Percentage survival of neurons cultured in the presence of $A \beta$ and baclofen for $20 \mathrm{~h}$. Down-regulation of GIRK channels by chronic baclofen treatment inhibited cell death, but the neurotoxicity of $A \beta_{42}$ was restored when neurons were co-cultured with the GABA $A_{B}$ receptor antagonist CGP55845 (CGP; $N=5$ experiments). ${ }^{*} P<$ $0.05,{ }^{* *} p<0.01,{ }^{* \star *} p<0.001,{ }^{* * * *} p<0.0001, n s$, not significant. 
A

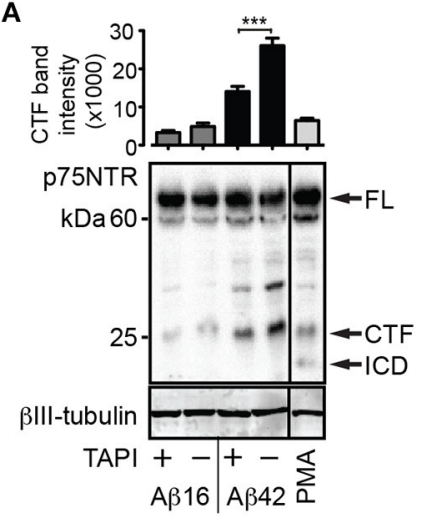

D

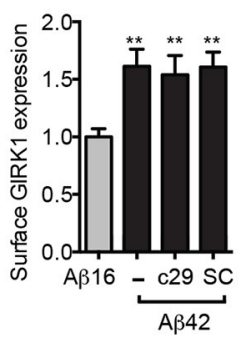

B

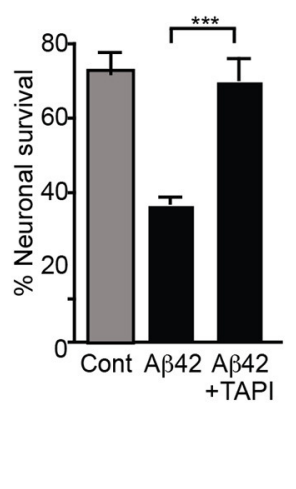

C

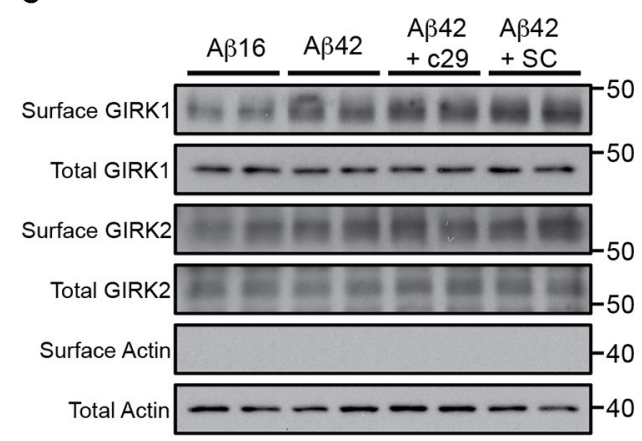

E
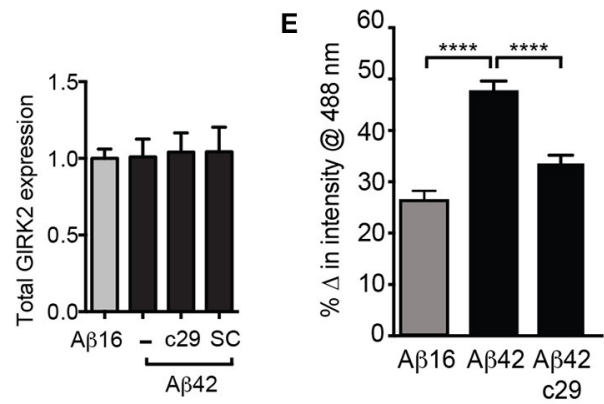

F

F
A $\beta 42$
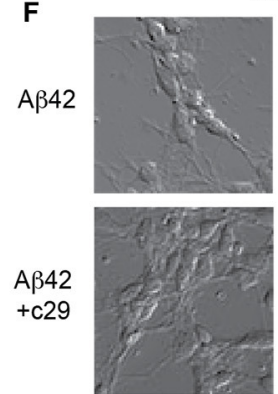

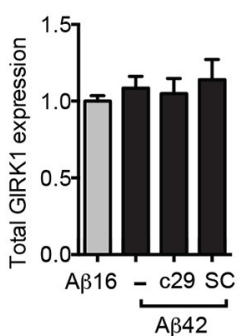

$0 \mathrm{~min}$
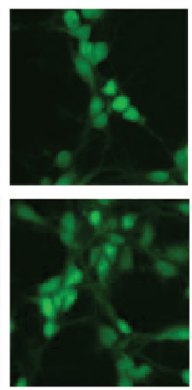

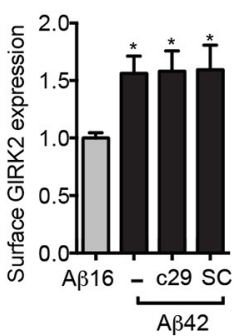

$160 \mathrm{~min}$

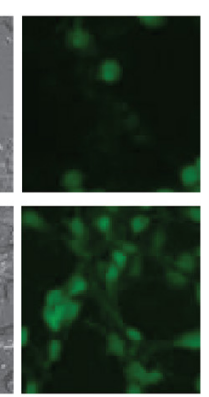

G

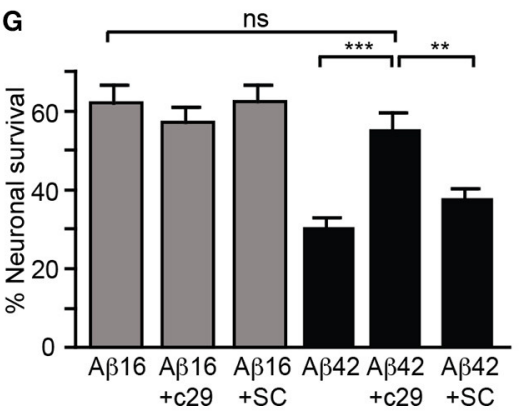

FIGURE 6 | A $\beta_{42}$-induced potassium efflux and apoptosis are mediated by p75 NTR. (A) Western blot of p75 NTR cleavage in the presence of A $\beta$ and TAPI or the cleavage stimulator PMA (positive control) for $3 \mathrm{~h}$ and quantification of the C-terminal fragment (CTF) band intensity (FL, full length; ICD, intracellular domain fragment; $N=2$ experiments). (B) Percentage survival of neurons cultured in the presence of $A \beta$ and treated with the metalloprotease inhibitor TAPI for $20 \mathrm{~h}$, which significantly inhibited $A \beta$-induced cell death. Western blots (C) and quantification (D) of total and surface GIRK1 and GIRK2 protein levels in hippocampal neurons treated for $2 \mathrm{~h}$ with either control $A \beta_{16}$ or oligomeric $A \beta_{42}$ and $c 29$ or scrambled (SC) peptides ( $N=8$ replicates). Neither peptide treatment altered the levels of $A \beta$-induced upregulation of surface GIRK channel subunits. (E) Average decrease in potassium concentration of individual neurons in cultures treated for 160 min with $A \beta_{42}$ and the dominant-negative p75 NTR peptide c29 ( $n=458$ neurons). (F) Representative relief contrast and fluorescence (Asante Potassium Green-2) photographs of neuronal cultures taken immediately and 160 min after $A \beta$ and c29 treatment. (G) Percentage survival of neurons cultured in the presence of $A \beta$ and control or c29 peptides over 20 h. c29 but not a scrambled peptide inhibited $A \beta_{42}$-initiated death $\left(N=3\right.$ experiments). ${ }^{*} p<0.05,{ }^{* \star} p<0.01,{ }^{* \star *} p<0.001,{ }^{* \star \star *} p<0.0001, n s$, not significant.

As $\mathrm{p} 75^{\mathrm{NTR}}$-mediated $\mathrm{PIP}_{2}$ generation and GIRK channelactivating signals were previously found to be dependent on metalloprotease cleavage of $\mathrm{p} 75^{\mathrm{NTR}}$ to its C-terminal fragment (Coulson et al., 2008), we determined whether $A \beta_{42}$ treatment induced $p 75^{\mathrm{NTR}}$ proteolysis. $A \beta_{42}$ but not $A \beta_{16}$ stimulated increased generation of the $\mathrm{p} 75^{\mathrm{NTR}} \mathrm{C}$-terminal fragment (Figure 6A). Furthermore, an inhibitor of the p $75^{\mathrm{NTR}}$ metalloprotease (TAPI) blocked both $\mathrm{A} \beta$-induced cleavage of $\mathrm{p} 75^{\mathrm{NTR}}$ and neuronal death (Figures $6 \mathrm{~A}, \mathbf{B}$ ), indicating that activation of $p 75^{\mathrm{NTR}}$ is necessary for $\mathrm{A} \beta$-induced cell death.

Finally, we treated neurons with a cell-permeable peptide inhibitor of the $\mathrm{p} 75^{\mathrm{NTR}} \mathrm{C}$-terminal fragment that initiates the GIRK channel activity pathway (Coulson et al., 2008) and which can act by a dominant-negative mechanism to prevent death signaling (Coulson et al., 2000). Treatment of neurons with this peptide, $c 29$, had no effect on $A \beta$-induced cell surface expression of GIRK subunits (Figures 6C,D), but significantly 


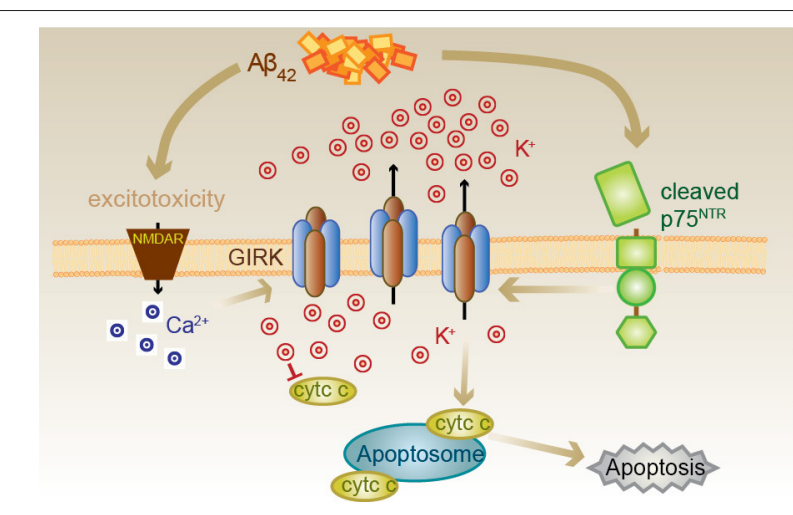

FIGURE 7 | Proposed A $\beta_{42}-p 75^{\text {NTR }}$-GIRK channel death signaling pathway. $A \beta_{42}$ excitotoxicity increases intracellular calcium in neurons via NMDA receptors (NMDAR), which triggers an increase in the number of GIRK channels at the cell surface. $A \beta_{42}$ also results in the cleavage of p $75^{\text {NTR }}$ to its C-terminal fragment, which can then activate the GIRK channels resident on the surface to promote a pathological potassium efflux. Lowered internal potassium concentration removes inhibition of apoptosome formation, thereby causing cell death. Cell death can be inhibited by raised extracellular potassium, the GIRK channel inhibitor tertiapin, chronic baclofen treatment removing GIRK channels from the cell surface, preventing p $75^{\text {NTR }}$ cleavage or treatment with a p $75^{\text {NTR }}$ signaling inhibitor (c29).

inhibited the enhanced potassium efflux from neurons cotreated with $\mathrm{A} \beta_{42}$ (Figures 6E,F). Furthermore, c29 peptide treatment significantly inhibited $A \beta_{42}$-induced neuronal death, whereas a cell-permeable scrambled control peptide had no effect (Figure 6G). Together, these results suggest that $\mathrm{p} 75^{\mathrm{NTR}}$ mediated signals induced by $A \beta_{42}$ are concomitantly required for potassium efflux through GIRK channels and subsequent neuronal death.

\section{DISCUSSION}

Here we describe a novel, $A \beta$-triggered apoptotic pathway in which exposure to excitotoxic $A \beta$ leads to upregulation and activation of GIRK channels, causing sustained potassium efflux from neurons and resulting in their apoptosis. Although, upregulation of GIRK channels is required for this death signaling, it appeared that this is not sufficient, with coincident activation of $\mathrm{p} 75^{\mathrm{NTR}}$ signaling by $\mathrm{A} \beta$ also being necessary for neuronal degeneration.

\section{Surface GIRK Channels Are Upregulated by $A \beta$}

Our first finding is that $A \beta$ mediates the upregulation of GIRK channel expression on the neuronal plasma membrane. Although, the reason for this was not investigated, it has previously been observed that robust activation of NMDA receptors leads to an increase in cell surface recruitment of GIRK channels (Chung et al., 2009a,b). Analogous to this situation, $A \beta$ can raise intracellular calcium levels by an NMDA receptordependent mechanism, and $A \beta$ has also been shown to cause aberrant NMDA receptor activity and hyperexcitability (Palop et al., 2007). Consistent with this, the NMDA receptor antagonist APV was observed to block $A \beta$-induced calcium influx, as well as GIRK-mediated potassium efflux. It is therefore possible that GIRK channels are upregulated by such mechanisms in the current study (Chung et al., 2009b; Yao et al., 2013).

An acute effect of the upregulation of GIRK channels was enhanced slow inhibitory neurotransmission within the hippocampal CA1 circuit. Recruitment of GIRK channels to the plasma membrane is also a critical step in the depotentiation of NMDA-receptor-driven LTP in the hippocampus (Chung et al., 2009a,b). Therefore, $A \beta$-mediated upregulation of GIRK channels likely causes persistent depression of synaptic activity as observed in the mouse model of Down's syndrome (Ts65Dn). GIRK currents recorded in hippocampal neurons of these animals, which overexpress GIRK channels due to an additional copy of the GIRK2 gene (in addition to the amyloid precursor protein gene), are significantly more sensitive to inhibitory input through $\mathrm{GABA}_{\mathrm{B}}$ receptors, which others have shown leads to an impairment of excitatory input and cognitive deficits (Harashima et al., 2006; Best et al., 2007). Moreover, a recent report demonstrated that $A \beta$ perfusion of hippocampal slices caused increased resistance of $\mathrm{CA} 3$ neurons to firing, an effect which was mediated by $\mathrm{GABA}_{B}$ and GIRK channel activity (Nava-Mesa et al., 2013). Our findings provide an explanation for previous reports that, although $A \beta$ is excitotoxic, neurons exposed to $A \beta$ become synaptically silent prior to their death (Palop et al., 2007; Palop and Mucke, 2010; Yao et al., 2013).

\section{Upregulated GIRK Channel Activity Is Necessary for $A \beta$-Induced Cell Death}

The upregulation of GIRK channels by $A \beta$ resulted in significant potassium efflux, demonstrated using electrophysiology and potassium imaging, that was required for subsequent neuronal death. In addition, blocking GIRK channels with tertiapin, or potassium efflux more generically, was sufficient to prevent this $\mathrm{A} \beta$-induced potassium loss and subsequent neuronal degeneration. Furthermore, chronic baclofen treatment also blocked $A \beta$-induced potassium efflux, prevented neuronal degeneration, and down-regulated surface GIRK channel expression. Although, it is possible that the baclofen treatment masked the toxic effect of $A \beta$ by an unrelated mechanism, taken together with our other data, the correlation between baclofen-induced down-regulation of GIRK channel activity and reduced $\mathrm{A} \beta$-toxicity is consistent with a causal relationship. Potassium dysregulation is a feature of Alzheimer's disease brain tissue (Roberts et al., 2016), and similar to our findings, others have shown that potassium efflux from cortical neurons can be promoted by $A \beta$, and that this efflux is required to cause subsequent degeneration, although the mechanism remains unclear (Yu et al., 1998; Shabala et al., 2010). Our data indicate that $A \beta_{42}$ treatment causes sufficient potassium to leave the cell to reduce the intracellular potassium concentration to approximately half $(80 \mathrm{mM})$, which in turn is permissive for the apoptosome to assemble and caspases to be activated, a finding that is consistent with previous reports (Cain et al., 2001; Coulson et al., 2008). In addition, our results strongly indicate that GIRK 
channels are key mediators of this critical apoptotic step. However, our findings do not rule out the possible involvement of other potassium channels in $\mathrm{A} \beta$-mediated neurotoxicity.

\section{Coincident Activation of $\mathrm{p} 75^{\mathrm{NTR}}$ and GIRK Channels Is Required to Induce Cell Death}

Although, upregulation of membrane GIRK channels and increased potassium efflux were directly associated with $A \beta$ induced neuronal degeneration, it remains unclear whether the pathological GIRK channel activation occurred by inhibitory neurotransmission and/or through a coincident $\mathrm{A} \beta$ activated pathway-such as that mediated by $\mathrm{p} 75^{\mathrm{NTR}}$. Although, neurotransmitter receptor activation may play a contributory role in the observed potassium efflux, chronic stimulation of $\mathrm{GABA}_{\mathrm{B}}$ receptors inhibited cell death, coincident with GIRK channels being removed from the cell surface. Likewise, it is unlikely that the channels were activated by $\mathrm{G}_{\mathrm{q}}$-coupled neurotransmitter receptor-mediated mechanisms, as these cause the hydrolysis of $\mathrm{PIP}_{2}$ and inhibit channel activity (Raveh et al., 2010), with $\mathrm{PIP}_{2}$ being required for GIRK channel opening. Several groups have previously reported that $\mathrm{p} 75^{\mathrm{NTR}}$ can increase PIP 2 levels via Rac1 (Gibon et al., 2015; Zeinieh et al., 2015), a necessary step for GIRK channel activation by p $75^{\text {NTR }}$ (Coulson et al., 2008). We therefore suggest that $\mathrm{p} 75^{\mathrm{NTR}}$ mediates pathological GIRK channel activity subsequent to $\mathrm{A} \beta$-induced channel upregulation, nominally $\sim 2-3 \mathrm{~h}$ after $\mathrm{A} \beta$ application.

Regardless of whether or not $\mathrm{p} 75^{\mathrm{NTR}}$ is directly responsible for GIRK channel activity, $\mathrm{p} 75^{\mathrm{NTR}}$ signaling is required for $\mathrm{A} \beta$ induced cell death, as blocking this signaling, even in the context of enhanced surface GIRK expression, prevented both loss of cellular potassium and cell death. $A \beta$ has been widely reported to activate $\mathrm{p} 75^{\mathrm{NTR}}$ either directly or indirectly, leading to neuronal degeneration; neurons with reduced $\mathrm{p} 75^{\mathrm{NTR}}$ expression or function are resistant to $\mathrm{A} \beta$-induced toxicity in vitro and in vivo (Yaar et al., 1997; Ivins et al., 1998; Tsukamoto et al., 2003; Sotthibundhu et al., 2008; Yang et al., 2008; Knowles et al., 2009; Yu et al., 2012). However, because p $75^{\mathrm{NTR}}$ can regulate a range of signaling pathways, the mechanism by which it mediates apoptosis in response to $A \beta$ has remained unclear (Coulson, 2006; Skeldal et al., 2011).

We suggest that $A \beta$ causes the induction of GIRK channel surface expression which, when activated acutely by traditional G-protein-coupled receptors, enhances inhibitory neurotransmission (Figure 7). However, sustained exposure to $\mathrm{A} \beta$ coincidently results in activation of $\mathrm{p} 75^{\mathrm{NTR}}$ cleavage and signaling pathways, one of which involves the activation of GIRK channels. As activation of GIRK channels by $\mathrm{p} 75^{\mathrm{NTR}}$ occurs through increased levels of $\mathrm{PIP}_{2}$ and independently of G-proteins
(Coulson et al., 2008), potassium efflux through GIRK channels could be sustained (Raveh et al., 2010). Sustained channel activity resulting in substantial potassium efflux then triggers apoptosis. However, alternatively, or coincident with $\mathrm{p} 75^{\mathrm{NTR}}$-mediated GIRK channel activity, other $\mathrm{p} 75^{\mathrm{NTR}}$-mediated signals (e.g., activation of c-jun kinase; Coulson, 2006) could facilitate the activation of the apoptosome via the mitochondrial death pathway in the context of already lowered intracellular potassium mediated via GIRK channels by other means.

\section{Summary}

In conclusion, we have demonstrated that exposure to excitotoxic $A \beta$ drives an increase in the number of surface GIRK channels which, when activated, can directly result in increased inhibitory neurotransmission and neuronal circuit silencing. Over a longer timescale, GIRK channel activity is a key mediator of neuronal degeneration and apoptosis. However, for this novel cell death pathway to proceed, it also requires signaling by $\mathrm{p} 75^{\mathrm{NTR}}$, which can be coincidently triggered by $\mathrm{A} \beta$ exposure, resulting in pathological GIRK channel activity.

\section{ETHICS STATEMENT}

All animal procedures were approved by the University of Queensland Animal Ethics Committee in accordance with the Australian code for the care and use of animals for scientific purposes (2013).

\section{AUTHOR CONTRIBUTIONS}

LM, VA, HG, PS, and EC designed the experiments and wrote the manuscript; LM, HG, VA, DM, SJ, and GK performed experiments; LM, HG, VA, DM, FM, and PS analyzed data and all authors discussed the work and commented on the manuscript.

\section{ACKNOWLEDGMENTS}

This work was supported by the National Health and Medical Research Council of Australia project grant (511107), a Career Development Award to EC, a CJ Martin Fellowship to VA, and Senior Research Fellowship to FM. It was also funded by a UniQuest Pty Ltd Pathfinder grant and a Queensland National and International Research Alliances Program grant to EC, the John T. Reid Charitable Trusts to VA, Australian Postgraduate Awards to LM and HG, and a University of Queensland International Scholarship to SJ. We would like to thank Luke Hammond (QBI) for assistance with microscopy and image analysis, Rick Webb (Centre for Microscopy and Microanalysis) for assistance with transmission electron microscopy, and Rowan Tweedale (QBI) for discussions and manuscript editing.

\section{REFERENCES}

Alberdi, E., Sanchez-Gomez, M. V., Cavaliere, F., Perez-Samartin, A., Zugaza, J. L., Trullas, R., et al. (2010). Amyloid $\beta$ oligomers induce $\mathrm{Ca}^{2+}$ dysregulation and neuronal death through activation of ionotropic glutamate receptors. Cell Calcium 47, 264-272. doi: 10.1016/j.ceca.2009.12.010

Anggono, V., Clem, R. L., and Huganir, R. L. (2011). PICK1 loss of function occludes homeostatic synaptic scaling. J. Neurosci. 31, 2188-2196. doi: 10.1523/JNEUROSCI.5633-10.2011

Ballard, C., Gauthier, S., Corbett, A., Brayne, C., Aarsland, D., and Jones, E. (2011). Alzheimer's disease. Lancet 377, 1019-1031. doi: 10.1016/S0140-6736(10)61349-9 
Best, T. K., Siarey, R. J., and Galdzicki, Z. (2007). Ts65Dn, a mouse model of Down syndrome, exhibits increased $\mathrm{GABA}^{\mathrm{B}}$-induced potassium current. J. Neurophysiol. 97, 892-900. doi: 10.1152/jn.00626.2006

Cain, K., Langlais, C., Sun, X. M., Brown, D. G., and Cohen, G. M. (2001). Physiological concentrations of $\mathrm{K}^{+}$inhibit cytochrome cdependent formation of the apoptosome. J. Biol. Chem. 276, 41985-41990. doi: 10.1074/jbc.M107419200

Chakravarthy, B., Gaudet, C., Menard, M., Atkinson, T., Brown, L., Laferla, F. M., et al. (2010). Amyloid-beta peptides stimulate the expression of the p75NTR neurotrophin receptor in SHSY5Y human neuroblastoma cells and $\mathrm{AD}$ transgenic mice. J. Alzheimers Dis. 19, 915-925. doi: 10.3233/JAD-2010-1288

Chung, H. J., Ge, W. P., Qian, X., Wiser, O., Jan, Y. N., and Jan, L. Y. (2009a). G protein-activated inwardly rectifying potassium channels mediate depotentiation of long-term potentiation. Proc. Natl. Acad. Sci. U.S.A. 106, 635-640. doi: 10.1073/pnas.0811685106

Chung, H. J., Qian, X., Ehlers, M., Jan, Y. N., and Jan, L. Y. (2009b). Neuronal activity regulates phosphorylation-dependent surface delivery of G proteinactivated inwardly rectifying potassium channels. Proc. Natl. Acad. Sci. U.S.A. 106, 629-634. doi: 10.1073/pnas.0811615106

Clancy, S. M., Boyer, S. B., and Slesinger, P. A. (2007). Coregulation of natively expressed pertussis toxin-sensitive muscarinic receptors with G-protein-activated potassium channels. J. Neurosci. 27, 6388-6399. doi: 10.1523/JNEUROSCI.1190-07.2007

Costantini, C., Rossi, F., Formaggio, E., Bernardoni, R., Cecconi, D., and DellaBianca, V. (2005). Characterization of the signaling pathway downstream p75 neurotrophin receptor involved in beta-amyloid peptide-dependent cell death. J. Mol. Neurosci. 25, 141-156. doi: 10.1385/JMN:25:2:141

Coulson, E. J. (2006). Does the p75 neurotrophin receptor mediate $A \beta$ induced toxicity in Alzheimer's disease? J. Neurochem. 98, 654-660. doi: 10.1111/j.1471-4159.2006.03905.x

Coulson, E. J., May, L. M., Osborne, S. L., Reid, K., Underwood, C. K., Meunier, F. A., et al. (2008). p75 neurotrophin receptor mediates neuronal cell death by activating GIRK channels through phosphatidylinositol 4,5-bisphosphate. J. Neurosci. 28, 315-324. doi: 10.1523/JNEUROSCI.2699-07.2008

Coulson, E. J., May, L. M., Sykes, A. M., and Hamlin, A. S. (2009). The role of the p75 neurotrophin receptor in cholinergic dysfunction in Alzheimer's disease. Neuroscientist 15, 317-323. doi: 10.1177/1073858408331376

Coulson, E. J., Reid, K., Baca, M., Shipham, K., Hulett, S. M., Kilpatrick, T. J., et al. (2000). Chopper, a new death domain of the p75 neurotrophin receptor which mediates rapid neuronal cell death. J. Biol. Chem. 275, 30537-30545. doi: 10.1074/jbc.M005214200

Dascal, N. (1997). Signalling via the G protein-activated $\mathrm{K}^{+}$channels. Cell. Signal. 9, 551-573. doi: 10.1016/S0898-6568(97)00095-8

De Felice, F. G., Velasco, P. T., Lambert, M. P., Viola, K., Fernandez, S. J., Ferreira, S. T., et al. (2007). Abeta oligomers induce neuronal oxidative stress through an N-methyl-D-aspartate receptor-dependent mechanism that is blocked by the Alzheimer drug memantine. J. Biol. Chem. 282, 11590-11601. doi: 10.1074/jbc.M607483200

Fowler, C. E., Aryal, P., Suen, K. F., and Slesinger, P. A. (2007). Evidence for association of $\mathrm{GABA}^{\mathrm{B}}$ receptors with Kir3 channels and regulators of G protein signalling (RGS4) proteins. J. Physiol. 580, 51-65. doi: 10.1113/jphysiol.2006.123216

Gibon, J., Buckley, S. M., Unsain, N., Kaartinen, V., Seguela, P., and Barker, P. A. (2015). proBDNF and p75NTR control excitability and persistent firing of cortical pyramidal neurons. J. Neurosci. 35, 9741-9753. doi: 10.1523/JNEUROSCI.4655-14.2015

Haass, C., and Selkoe, D. J. (2007). Soluble protein oligomers in neurodegeneration: lessons from the Alzheimer's amyloid $\beta$-peptide. Nat. Rev. Mol. Cell Biol. 8, 101-112. doi: 10.1038/nrm2101

Harashima, C., Jacobowitz, D. M., Witta, J., Borke, R. C., Best, T. K., Siarey, R. J., et al. (2006). Abnormal expression of the G-protein-activated inwardly rectifying potassium channel 2 (GIRK2) in hippocampus, frontal cortex, and substantia nigra of Ts65Dn mouse: A model of Down syndrome. J. Comp. Neurol. 494, 815-833. doi: 10.1002/cne.20844

Hardy, J., and Selkoe, D. J. (2002). The amyloid hypothesis of Alzheimer's disease: progress and problems on the road to therapeutics. Science 297, 353-356. doi: $10.1126 /$ science. 1072994
Ho, A., Schwarze, S. R., Mermelstein, S. J., Waksman, G., and Dowdy, S. F. (2001). Synthetic protein transduction domains: enhanced transduction potential in vitro and in vivo. Cancer Res. 61, 474-477.

Huang, C. L., Feng, S., and Hilgemann, D. W. (1998). Direct activation of inward rectifier potassium channels by PIP2 and its stabilization by Gbetagamma. Nature 391, 803-806. doi: 10.1038/35882

Ibanez, C. F., and Simi, A. (2012). p75 neurotrophin receptor signaling in nervous system injury and degeneration: paradox and opportunity. Trends Neurosci. 35, 431-440. doi: 10.1016/j.tins.2012.03.007

Ivins, K. J., Bui, E. T., and Cotman, C. W. (1998). Beta-amyloid induces local neurite degeneration in cultured hippocampal neurons: evidence for neuritic apoptosis. Neurobiol. Dis. 5, 365-378. doi: 10.1006/nbdi.1998.0228

Knowles, J. K., Rajadas, J., Nguyen, T. V., Yang, T., LeMieux, M. C., Vander Griend, L., et al. (2009). The p75 neurotrophin receptor promotes amyloid- $\beta 1-42-$ induced neuritic dystrophy in vitro and in vivo. J. Neurosci. 29, 10627-10637. doi: 10.1523/JNEUROSCI.0620-09.2009

Matusica, D., Skeldal, S., Sykes, A. M., Palstra, N., Sharma, A., and Coulson, E. J. (2013). An intracellular domain fragment of the p75 neurotrophin receptor (p75NTR) enhances tropomyosin receptor kinase A (TrkA) receptor function. J. Biol. Chem. 288, 11144-11154. doi: 10.1074/jbc.M112.436469

Mucke, L., Masliah, E., Yu, G. Q., Mallory, M., Rockenstein, E. M., Tatsuno, G., et al. (2000). High-level neuronal expression of A $\beta$ 1-42 in wild-type human amyloid protein precursor transgenic mice: synaptotoxicity without plaque formation. J. Neurosci. 20, 4050-4058.

Mufson, E. J., and Kordower, J. H. (1992). Cortical neurons express nerve growth factor receptors in advanced age and Alzheimer disease. Proc. Natl. Acad. Sci. U.S.A. 89, 569-573. doi: 10.1073/pnas.89.2.569

Nava-Mesa, M. O., Jimenez-Diaz, L., Yajeya, J., and Navarro-Lopez, J. D. (2013). Amyloid-beta induces synaptic dysfunction through $\mathrm{G}$ protein-gated inwardly rectifying potassium channels in the fimbria-CA3 hippocampal synapse. Front. Cell. Neurosci. 7:117. doi: 10.3389/fncel.2013.00117

Ondrejcak, T., Klyubin, I., Hu, N. W., Barry, A. E., Cullen, W. K., and Rowan, M. J. (2010). Alzheimer's disease amyloid $\beta$-protein and synaptic function. Neuromol. Med. 12, 13-26. doi: 10.1007/s12017-009-8091-0

Palop, J. J., Chin, J., Roberson, E. D., Wang, J., Thwin, M. T., Bien-Ly, N., et al. (2007). Aberrant excitatory neuronal activity and compensatory remodeling of inhibitory hippocampal circuits in mouse models of Alzheimer's disease. Neuron 55, 697-711. doi: 10.1016/j.neuron.2007.07.025

Palop, J. J., and Mucke, L. (2010). Amyloid-beta-induced neuronal dysfunction in Alzheimer's disease: from synapses toward neural networks. Nat. Neurosci. 13, 812-818. doi: 10.1038/nn.2583

Perez, S. E., He, B., Muhammad, N., Oh, K. J., Fahnestock, M., Ikonomovic, M. D., et al. (2011). Cholinotrophic basal forebrain system alterations in 3xTg-AD transgenic mice. Neurobiol. Dis. 41, 338-352. doi: 10.1016/j.nbd.2010.10.002

Perez-Cruz, C., Nolte, M. W., van Gaalen, M. M., Rustay, N. R., Termont, A., Tanghe, A., et al. (2011). Reduced spine density in specific regions of CA1 pyramidal neurons in two transgenic mouse models of Alzheimer's disease. J. Neurosci. 31, 3926-3934. doi: 10.1523/JNEUROSCI.6142-10.2011

Raveh, A., Cooper, A., Guy-David, L., and Reuveny, E. (2010). Nonenzymatic rapid control of GIRK channel function by a $\mathrm{G}$ protein-coupled receptor kinase. Cell 143, 750-760. doi: 10.1016/j.cell.2010.10.018

Riedl, S. J., and Salvesen, G. S. (2007). The apoptosome: signalling platform of cell death. Nat. Rev. Mol. Cell Biol. 8, 405-413. doi: 10.1038/nrm2153

Rimmele, T. S., and Chatton, J. Y. (2014). A novel optical intracellular imaging approach for potassium dynamics in astrocytes. PLoS ONE 9:e109243. doi: 10.1371/journal.pone.0109243

Roberts, B. R., Doecke, J. D., Rembach, A., Yévenes, L. F., Fowler, C. J., McLean, C. A., et al. (2016). The AIBL research group8 Rubidium and potassium levels are altered in Alzheimer's disease brain and blood but not in cerebrospinal fluid. Acta Neuropathol. Commun. 4:119. doi: 10.1186/s40478-016-0390-8

Scanziani, M. (2000). GABA spillover activates postsynaptic GABA $^{\mathrm{B}}$ receptors to control rhythmic hippocampal activity. Neuron 25, 673-681. doi: 10.1016/S0896-6273(00)81069-7

Shabala, L., Howells, C., West, A. K., and Chung, R. S. (2010). Prolonged Abeta treatment leads to impairment in the ability of primary cortical neurons to maintain $\mathrm{K}^{+}$and $\mathrm{Ca}^{2+}$ homeostasis. Mol. Neurodegener. 5:30. doi: $10.1186 / 1750-1326-5-30$ 
Shankar, G. M., Li, S., Mehta, T. H., Garcia-Munoz, A., Shepardson, N. E., Smith, I., et al. (2008). Amyloid- $\beta$ protein dimers isolated directly from Alzheimer's brains impair synaptic plasticity and memory. Nat. Med. 14, 837-842. doi: 10.1038/nm1782

Skeldal, S., Matusica, D., Nykjaer, A., and Coulson, E. J. (2011). Proteolytic processing of the p75 neurotrophin receptor: a prerequisite for signalling?: Neuronal life, growth and death signalling are crucially regulated by intramembrane proteolysis and trafficking of p75NTR. Bioessays 33, 614-625. doi: 10.1002/bies.201100036

Smith, D. L., Pozueta, J., Gong, B., Arancio, O., and Shelanski, M. (2009). Reversal of long-term dendritic spine alterations in Alzheimer disease models. Proc. Natl. Acad. Sci. U.S.A. 106, 16877-16882. doi: 10.1073/pnas.0908 706106

Sotthibundhu, A., Sykes, A. M., Fox, B., Underwood, C. K., Thangnipon, W., and Coulson, E. J. (2008). $\beta$-amyloid1-42 induces neuronal death through the p75 neurotrophin receptor. J. Neurosci. 28, 3941-3946. doi: 10.1523/JNEUROSCI.0350-08.2008

Tsukamoto, E., Hashimoto, Y., Kanekura, K., Niikura, T., Aiso, S., and Nishimoto, I. (2003). Characterization of the toxic mechanism triggered by Alzheimer's amyloid-beta peptides via p75 neurotrophin receptor in neuronal hybrid cells. J. Neurosci. Res. 73, 627-636. doi: 10.1002/jnr.10703

Walsh, D. M., Klyubin, I., Fadeeva, J. V., Cullen, W. K., Anwyl, R., Wolfe, M. S., et al. (2002). Naturally secreted oligomers of amyloid $\beta$ protein potently inhibit hippocampal long-term potentiation in vivo. Nature 416, 535-539. doi: $10.1038 / 416535 a$

Walsh, D. M., and Selkoe, D. J. (2007). A beta oligomers - a decade of discovery. J. Neurochem. 101, 1172-1184. doi: 10.1111/j.1471-4159.2006. 04426.x

Wang, Y. J., Wang, X., Lu, J. J., Li, Q. X., Gao, C. Y., Liu, X. H., et al. (2011). p75NTR regulates $A \beta$ deposition by increasing $A \beta$ production but inhibiting A $\beta$ aggregation with its extracellular domain. J. Neurosci. 31, 2292-2304. doi: 10.1523/JNEUROSCI.2733-10.2011

Yaar, M., Zhai, S., Pilch, P. F., Doyle, S. M., Eisenhauer, P. B., Fine, R. E., et al. (1997). Binding of beta-amyloid to the p75 neurotrophin receptor induces apoptosis. A possible mechanism for Alzheimer's disease. J. Clin. Invest. 100, 2333-2340. doi: 10.1172/JCI119772
Yang, T., Knowles, J. K., Lu, Q., Zhang, H., Arancio, O., Moore, L. A., et al. (2008). Small molecule, non-peptide p75 ligands inhibit A $\beta$ induced neurodegeneration and synaptic impairment. PLOS ONE 3:e3604. doi: 10.1371/journal.pone.0003604

Yao, W., Zou, H. J., Sun, D., and Ren, S. Q. (2013). Abeta induces acute depression of excitatory glutamatergic synaptic transmission through distinct phosphatase-dependent mechanisms in rat CA1 pyramidal neurons. Brain Res. 1515, 88-97. doi: 10.1016/j.brainres.2013.03.049

Yu, H., Yang, M., Wang, Y., Xiao, R., and Zhou, X. F. (2012). p75NTR is mainly responsible for Abeta toxicity but not for its internalization: a primary study. Neurol. Sci. 33, 1043-1050. doi: 10.1007/s10072-011-0892-x

Yu, S. P., and Choi, D. W. (2000). Ions, cell volume, and apoptosis. Proc. Natl. Acad. Sci. U.S.A. 97, 9360-9362. doi: 10.1073/pnas.97.17.9360

Yu, S. P., Farhangrazi, Z. S., Ying, H. S., Yeh, C. H., and Choi, D. W. (1998). Enhancement of outward potassium current may participate in betaamyloid peptide-induced cortical neuronal death. Neurobiol. Dis. 5, 81-88. doi: 10.1006/nbdi.1998.0186

Zeinieh, M., Salehi, A., Rajkumar, V., and Barker, P. A. (2015). p75NTR-dependent Racl activation requires receptor cleavage and activation of an NRAGE and NEDD9 signaling cascade. J. Cell Sci. 128, 447-459. doi: 10.1242/jcs.152173

Zhang, X., Loijens, J. C., Boronenkov, I. V., Parker, G. J., Norris, F. A., Chen, J., et al. (1997). Phosphatidylinositol-4-phosphate 5-kinase isozymes catalyze the synthesis of 3-phosphate-containing phosphatidylinositol signaling molecules. J. Biol. Chem. 272, 17756-17761. doi: 10.1074/jbc.272.28.17756

Conflict of Interest Statement: The authors declare that the research was conducted in the absence of any commercial or financial relationships that could be construed as a potential conflict of interest.

Copyright (C) 2017 May, Anggono, Gooch, Jang, Matusica, Kerbler, Meunier, Sah and Coulson. This is an open-access article distributed under the terms of the Creative Commons Attribution License (CC BY). The use, distribution or reproduction in other forums is permitted, provided the original author(s) or licensor are credited and that the original publication in this journal is cited, in accordance with accepted academic practice. No use, distribution or reproduction is permitted which does not comply with these terms. 